INTERNATIONAL MONETARY FUND

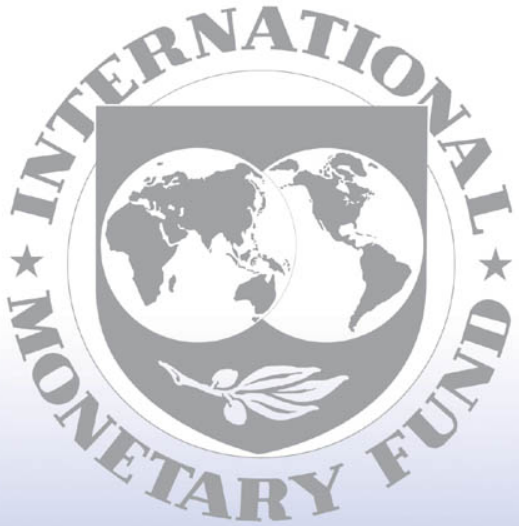

Staff

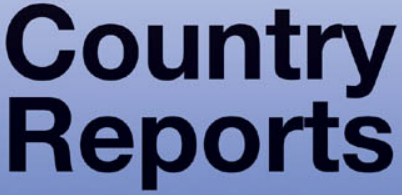




\section{Guinea: Poverty Reduction Strategy Paper Progress Report}

Poverty Reduction Strategy Papers (PRSPs) are prepared by member countries in broad consultation with stakeholders and development partners, including the staffs of the World Bank and the IMF. Updated every three years with annual progress reports, they describe the country's macroeconomic, structural, and social policies in support of growth and poverty reduction, as well as associated external financing needs and major sources of financing. This country document for Guinea, dated April 2004, is being made available on the IMF website by agreement with the member country as a service to users of the IMF website.

To assist the IMF in evaluating the publication policy, reader comments are invited and may be sent by e-mail to publicationpolicy@imf.org.

Copies of this report are available to the public from

International Monetary Fund • Publication Services

$70019^{\text {th }}$ Street, N.W. • Washington, D.C. 20431

Telephone: (202) 623-7430 • Telefax: (202) 623-7201

E-mail: publications@imf.org •Internet: http://www.imf.org

Price: $\$ 15.00$ a copy

\section{International Monetary Fund}

Washington, D.C. 
This page intentionally left blank 
REPUBLIC OF GUINEA

MINISTRY OF ECONOMY AND FINANCE

PERMANENT SECRETARIAT FOR THE

POVERTY REDUCTION STRATEGY (PS/PRS) 


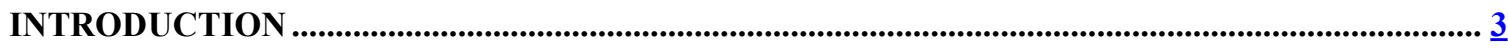

1. PRS CONTEXT AND IMPLEMENTATION_.............................................................................. 4

2. PRS IMPLEMENTATION ......................................................................................................... $\underline{5}$

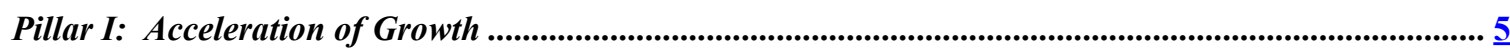

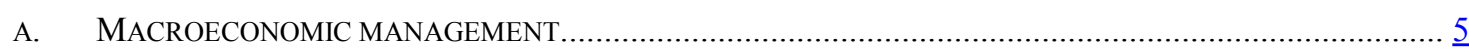

B. PUBLIC ENTERPRISE REFORM AND GOVERNMENT DIVESTMENT …............................................... $\frac{7}{8}$

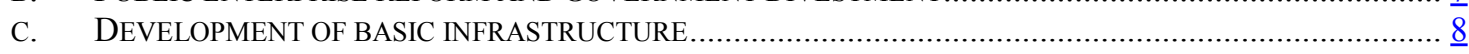

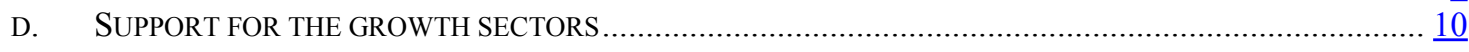

Pillar II: Development and Equitable Access to Basic Services ............................................................. 13

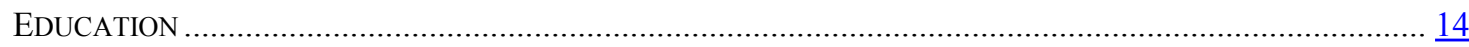

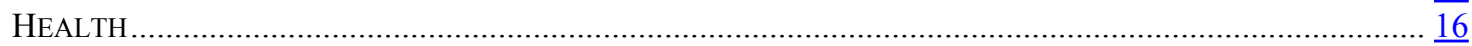

Pillar III: Improved Governance and Institutional and Human Capacity Building ................................ 20

3. LESSONS DRAWN FROM PRS IMPLEMENTATION: ........................................................ 22

Summary Table of the Outcomes of PRS Implementation ........................................................................... 24

ANNEX I: MOBILIZATION AND USE OF HIPC RESOURCES ..................................................... 29

ANNEX II: PROCESS OF PRS FORMULATION AND IMPLEMENTATION ................................... 31

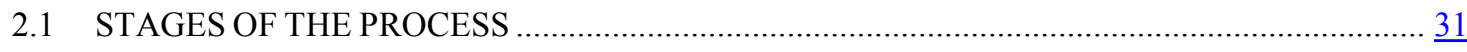

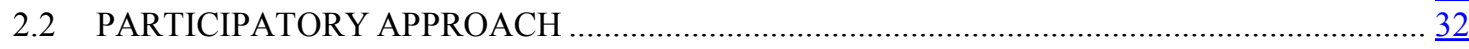

ANNEX III: PRS MONITORING AND EVALUATION SYSTEM..................................................... 35

a) Conceptual framework of the monitoring and evaluation system ......................................... $\underline{35}$

b) Indicators for monitoring the PRS.............................................................................. $\underline{36}$

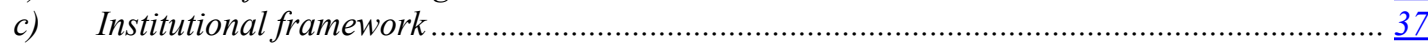

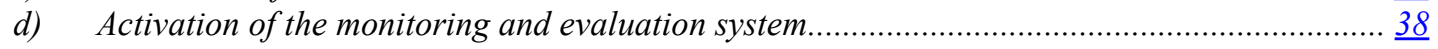




\section{INTRODUCTION}

1. Guinea began the process of formulating and implementing its poverty reduction strategy (PRS) in 2000. After two years of reflection and consensus building involving all the national stakeholders, the final PRS was adopted by the government in January 2002.

2. The general objective of the strategy is to significantly and sustainably reduce poverty in Guinea, by augmenting the income and welfare of the population, in particular the poor. The quantitative objectives included the following:

In the medium term (2002-2005):

- an average annual GDP growth rate of 5 percent in real terms between 2002 and 2005, as opposed to 3.7 percent between 1996 and 2000;

- increase the GDP per capita growth rate to an annual average of 1.9 percent between 2002 and 2005;

In the long term (2010):

- reduce the incidence of monetary poverty at the national level from 40.3 percent in 1994 to 30 percent in 2010, and from 52.5 to 38 percent in the rural areas during the same period;

- raise the gross primary school enrolment ratio from 56.7 percent in 1999/2000 to 100 percent in 2010 and the gross enrolment ratio for girls from 44.3 percent to 100 percent over the same period;

- reduce the infant mortality rate from 98 per mil in 1999 to 70 per mil in 2005 and to 50 per mil in 2010 ;

- increase the rate of access to drinking water from 49 percent in 1999 to 80 percent in 2005 and 100 percent in 2010.

3. To achieve these objectives, the strategy is built around three main pillars:

- acceleration of economic growth with greater income-generating opportunities for the poor;

- delivery of and equitable access to basic social services;

- enhanced governance and institutional and human capacity building.

4. The purpose of this paper is to provide an initial progress report on implementation of the strategy and to draw lessons from it for the PRS review scheduled for 2004. A revised macroeconomic framework is presented in Appendix I. 


\section{PRS CONTEXT AND IMPLEMENTATION}

5. Since 2000, Guinea was faced by a number of exogenous shocks (continuing armed conflicts in the sub region, rebel attacks on the national territory, rising oil prices, declining prices of export products, and dwindling foreign financing) and endogenous shocks (serious disruptions in rainfall patterns).

6. The continued armed conflicts in Liberia and Sierra Leone and the political and military crises that occurred in Guinea-Bissau and Côte d'Ivoire have seriously affected the country's economic and social equilibrium. Before the Ivorian crisis, some 151,000 refugees were living in the country, of which 101,000 were in camps and another 50,000 in the main cities. ${ }^{1}$ In addition to the pressure on basic social services, including health, environment and security, these conflicts resulted in major financial costs, in terms of fiscal expenditure and shortfalls in resource transfers from Guineans living in the affected countries. ${ }^{2}$

7. Furthermore, Guinea was the victim of rebel attacks from September 2000 to June 2001. Waged on various fronts, these attacks affected the entire border with Liberia and Sierra Leone, an area of over 1,200 km. They have caused the loss of many human lives, massive displacements of persons in the border areas, destruction of basic infrastructure, and slower economic growth. ${ }^{3}$

8. The high financial cost of efforts to secure the national territory has weighed heavily on fiscal balance in recent years.

9. Regarding changes in the terms of trade, most of the country's chief export products (bauxite, diamonds, coffee, gold, etc.) continued to stagnate on the world markets, at prices that were generally lower than those recorded in 1997 and 1998. For example, the price of a ton of bauxite, the country's main export commodity, was US\$21.50 in 2000, US\$23.70 in 2001 and US\$20.70 in 2003, as opposed to US\$25.20 in 1997 and US\$24.30 in 1998. The prices of cotton and coffee respectively changed from US\$1.45 to US\$2.26 per ton in 2003 and from US\$1.63 to US\$1.02 per ton between 1998 and 2002.

10. By contrast, the cost of oil imports rose from US\$66.48 million in 1999 to US $\$ 120.2$ million in $2003,{ }^{4}$ representing an 80 -percent rise in the oil bill over four years.

11. Other no less important factors considerably affected the country's economic performance, namely below-average rainfall in 2002 and water and power shortages in the first half of 2003, with serious repercussions on SME/SMI activity.

\footnotetext{
${ }^{1}$ Source: Ministry of Local Government and Decentralization.

${ }^{2}$ It is estimated that about 1 million Guineans live in the countries of the sub region.

${ }^{3}$ In 2000 and 2001, the national GDP growth rate was 1.9 and 3.6 percent, respectively, in real terms, compared with a rate of about 4 percent between 1996 and 1999. The rural sector was the most affected by the crisis, with a 2.3-percent decline in GDP in 2000.

${ }^{4}$ Source: Data from the macroeconomic framework, January 2003.
} 
12. In the area of partnership for development, Guinea has benefited from the HIPC Initiative since 2001. Under that Initiative, GF 40 billion was raised in 2001, GF 69.5 billion in 2002, and GF 81.9 billion in 2003, which adds up to US\$96 million for the three years. Since the process of PRS formulation and implementation was launched, Guinea has received only two loans for budgetary support in 2001: the World Bank SAC IV (US\$50 million) and the AfDB SAL III (12.25 million units of account or some US\$16 million), totaling US\$66 million.

13. It is in this particularly difficult context that PRS implementation was launched and pursued by the government, with the contribution of all the national stakeholders.

\section{PRS IMPLEMENTATION}

\section{Pillar I: Acceleration of Growth}

\section{a. Macroeconomic management}

14. The strategy hinged on: (i) macroeconomic and financial stabilization (tax and fiscal policy, monetary policy, and financial system reform), development of basic infrastructure (water, electricity, transportation, telecommunications), and support for the growth sectors.

15. Several measures were taken at the institutional, technical, and human levels to improve the mobilization of fiscal resources, notably: (i) restructuring the tax administrations by separating the tax administration and supervision functions (DNCFA), ${ }^{5}$ creation of a valuation office within the Customs Administration and implementation of a single customs clearance procedure; ${ }^{6}$ (ii) updating and upgrading the computer system in the customs departments, computerizing the DNCFA and connecting it with Customs and Tax departments, and tapping into the expenditure chain in order to monitor imports, tax returns, and procurement of goods and services to government agencies.

16. In the same spirit, in-depth investigations were conducted in large enterprises, those subject to the VAT and SMEs. The results of this exercise made it possible to update and complete the taxpayer file.

17. This set of measures, plus the setting of quantitative targets to be met by the revenue agencies, and arrangements for close monitoring of outcomes, resulted in the government's current revenue increasing from GF 593.3 to 763.9 billion (i.e., from 10.9

\footnotetext{
${ }^{5}$ In 2001, the tax supervision service became independent of the National Directorate of Taxes. The DNCFA so created is tasked with combating fraud and tax evasion. Its activities range from tax investigations, verification of tax returns, and tax collection and enforcement in cases of delinquency to finding taxpayers that are not registered on the rolls or that are subject to VAT but still operate in the informal sector.

${ }^{6}$ The single customs clearance procedure has been operational since April 2003 and is connected online with the valuation database.
} 
to 12 percent of GDP) between 2000 and 2002. After the exceptional performance of 2002 and during the first half of 2003, the overall outturn for 2003 was mixed, with GF 754 billion realized, owing in particular to the decrease in mining revenue (mining revenue declined from GF 166 billion in 2001 to GF 105.8 billion in 2003.)

18. Expenditures rose because of rebel attacks on the country and heightened insecurity in the sub region. In addition, major efforts were expended on the priority sectors.

Table 1. Trends in Public Finance

\begin{tabular}{lrrrrrrr}
\hline & 1997 & 1998 & 1999 & 2000 & 2001 & 2002 & 2003 \\
\hline REVENUE AND GRANTS & 611.3 & 618.6 & 628.3 & 718.6 & 874.3 & 935.2 & $1,048.9$ \\
Revenue & 475.9 & 488.8 & 517.2 & 593.3 & 671.5 & 763.9 & 754.1 \\
Grants & & & & & & \\
incl. HIPC & 135.4 & 129.8 & 111.1 & 125.3 & 202.8 & 171.3 & 294.8 \\
TOTAL EXPENDITURE & & & & & 40.1 & 69.5 & 81.9 \\
Current Expenditure & 732.5 & 646.7 & 773.4 & 893.6 & $1,113.8$ & $1,281.8$ & $1,441.8$ \\
Investment & 383.4 & 389.7 & 429.5 & 509.4 & 672.7 & 776.1 & 923.8 \\
$\begin{array}{l}\text { Debt Service } \\
\text { Interest }\end{array}$ & 349.1 & 257.0 & 343.9 & 386.67 & 422.1 & 493.5 & 518.0 \\
$\quad$ Principal & 149.1 & 143.0 & 162.7 & 209.0 & 224.5 & 296.4 & 395.8 \\
$\begin{array}{l}\text { Budget Surplus/Deficit } \\
\text { (percentage of GDP) }\end{array}$ & 67.5 & 64.1 & 74.5 & 94.8 & 89.6 & 105.3 & 147.4 \\
\hline
\end{tabular}

Source: MP/DNP Data from the Macroeconomic Framework and TOFE (MEF/DNB)

19. Weak foreign budgetary assistance combined with increasing expenditure put stress on the budget, the balance of payments, and on general price levels starting in 2003. The budget deficit rose to almost 10 percent of GDP in 2003, far exceeding the target of 3-5 percent set in the PRS.

20. In the monetary area, as envisaged in the PRSP, the government continued to use indirect instruments to control liquidity: reserve requirements, open market operations, Treasury bills, and lead interest rates. Since January 1, 2003, the minimum deposit rate declined from 7.4 percent to 6.5 percent and the lending rate was held at 21.25 percent. 
21. Nonetheless, the persistent budget deficit and its financing through the banks severely constrained monetary policy performance. In 2003, the budget deficit was largely financed by the banking system (76.8 percent of the total deficit). The BCRG alone financed 43.5 percent, which led to considerable deterioration $\mathrm{n}$ the main monetary indicators. The money supply increased by 35.3 percent at end-December 2003, as opposed to 19.2 percent at the beginning of the year; and the inflation rate (on a year-onyear basis) rose to 14.8 percent in 2003 from 6.1 percent in 2002 .

\section{b. Public enterprise reform and government divestment}

22. The reform underlying the PRS included the liquidation of enterprises deemed to be nonviable, privatization of those that could potentially become profitable, and options to be determined for public utilities and for mining companies. The three major goals of the reform were to: reduce the financial burden of the semipublic sector on the state budget, improve the development prospects of the enterprises to be kept in the government's portfolio, and enhance the country's overall economic and social development framework.

23. In this regard, the government launched a new reform program in 2000, with World Bank support, covering 62 enterprises. For its implementation, an appropriate legal and institutional framework was created: adoption and promulgation of Law L/2001/018/AN of October 27, 2001 on the reform, creation of a Privatization Unit, and set up by the Divestment Strategy Committee. Despite the delay caused by the legal and regulatory arrangements, the actions described below were taken:

- placement of the mining equipment and infrastructure of Friguia and SBK under a management contract;

- $\quad$ liquidation of: OCR, DIVERMA, APILEC, SOGETRAG, and ONACIG; ${ }^{7}$

- dissolution and sale of the assets of three enterprises: Sanoyah textile plant, Patrice Lumumba print shop, and Air-Guinée;

- long-term leasing of the GHU plant; and

- sale of the shares in SOMIAG.

24. The reform program also includes coaching for retraining/re-employment of those persons affected by the privatizations. As of December 31, 2003, the financial incidence of severance pay amounted to GF 6.26 billion.

25. 2004 will be marked, inter alia, by the franchising of SAKOBA (Koba Fish Farming Company), the sale of the government's shares in four companies (SOGUIRUSSE, SOMCAG, ENTAG, and SOPROCHIM), the liquidation of seven public enterprises (SEEG, SONEG, SOGEL, ENELGUI, SOGUITRO, SOLOPRIMO, and SOMIDRAT), the privatization of FRIGUIA and SBK.

\footnotetext{
${ }^{7}$ OCR: Central Supplies Office; DIVERMA: Hunting Rifles and Ammunition Import Company; APILEC: Mineral Block Production Workshop; SOGETRAG: Guinea General Transportation Company; ONACIF: Guinea National Cinematography and Videography Office.
} 


\section{c. Development of basic infrastructure}

26. Infrastructure development was one of the key provisions in the PRS for fostering growth and reducing poverty.

27. In the area of transportation and public works, priority was given to road transport, by opening up access to production areas, improving the conditions of passenger transport, and strengthening the competitiveness of the national economy. To that end, the following plans were made for 2001-03:

\begin{tabular}{|c|c|}
\hline Planned & Delivered $^{1 /}$ \\
\hline $\begin{array}{l}\text { - } \text { Repair of } 1,483.6 \mathrm{~km} \text { of rural roads } \\
\text { - } \text { Maintenance of } 4,647 \mathrm{~km} \text { of roads, of } \\
\text { which } 1,263 \mathrm{~km} \text { using the labor-intensive } \\
\text { approach } \\
\text { - } \quad \text { Construction of } 1,771 \mathrm{~lm} \text { of crossings } \\
\text { - } \quad \text { National capacity building and } \\
\text { redeployment in sectoral planning and } \\
\text { management } \\
\text { - SME/SMI promotion } \\
\text { Over the period } 2002-2007 \text { : } \\
\text { - } \quad \text { Regular maintenance of } 1,380 \mathrm{~km} \text { of rural } \\
\text { roads } \\
\text { - Repair of } 713 \mathrm{~km} \text { of rural roads } \\
\text { - } \text { Reinforcement of } 604 \mathrm{~km} \text { of paved roads } \\
\text { - Construction of } 2,880 \mathrm{~lm} \text { of concrete } \\
\text { bridges } \\
\text { - Completion of } 1,169 \mathrm{~km} \text { of paved roads }\end{array}$ & $\begin{array}{l}\text { - } 1,078 \mathrm{~km} \text { of rural roads repaired (484 km } \\
\text { in } 2001,138 \text { in } 2002 \text {, and } 457 \text { in } 2003) \text { at a } \\
\text { performance rate of } 72 \text { percent } \\
\text { - } 4,700 \mathrm{~km} \text { of roads maintained }(1,490 \mathrm{~km} \text { in } \\
20901,2,577 \text { in } 2002 \text {, and } 650 \mathrm{~km} \text { in } 2003) \\
\text { at a performance rate of } 101.5 \text { percent } \\
\text { - Construction of } 1,791 \mathrm{~lm} \text { of crossings at a } \\
\text { performance rate of } 101.1 \text { percent } \\
\text { - Continued paving of the strategic Kankan- } \\
\text { Kouremalé highway, eliminating the ferries } \\
\text { and building a bridge } 495 \text { lm long over the } \\
\text { Niger river and another one } 245 \text { lm long } \\
\text { over the Tinkisso river } \\
\text { - Paving the roads from Tanéné to Fria } \\
\text { (60 km), from Tanéné to Koba (45 km), the } \\
\text { access road to Bel Air ( } 25 \mathrm{~km}) \text {, the road } \\
\text { from Boké to Kamsar ( } 45 \mathrm{~km} \text { ), from Boké } \\
\text { to Sangaredi (70 km), and from Lambanyi } \\
\text { to Sonfonia station in Conakry (9.25 km) } \\
\text { - Repair of all the bridges between Coyah } \\
\text { and Pamélap } \\
\text { Construction of a bridge over the Fatala } \\
\text { (work in progress, nearing completion) } \\
\text { Maintenance of all national and regional } \\
\text { roads }\end{array}$ \\
\hline
\end{tabular}

28. In the energy sector, the number of hookups to the power grid increased from 71,738 in 2000 to 118,679 in 2003 (from 48,979 to 88,167 in Conakry), or a 65-percent increase. 
29. However, it should be noted that there are still serious shortages in the water and power supply in Conakry and in some large cities in the interior. In addition to the negative impact on the living standards of the population, these shortages slow down economic growth and have high fiscal costs, in terms of subsidies to the supplier.

\begin{tabular}{|c|c|}
\hline Planned & Delivered \\
\hline $\begin{array}{l}\text { PRSP plans for the first phase (2001-2003) of } \\
\text { the ten-year investment program: } \\
\text { - } \quad \text { Completion of the work on the third Water } \\
\text { and Sanitation Project } \\
\text { - } \quad \text { Extension of the tertiary supply network by } \\
482 \mathrm{~km} \text { and } 29,000 \text { new hookups } \\
\text { - } \quad \text { Increase from } 72 \text { to } 82 \text { percent in the } \\
\text { coverage rate for Conakry and from } 41 \text { to } \\
46 \text { percent for cities in the interior } \\
\text { - Completion of the water supply networks } \\
\text { for the cities of Télimélé, Gaoual, } \\
\text { Lélouma, and Youmou; and } \\
\text { - Reinforcement of existing facilities in } \\
\text { major cities } \\
800 \text { water supply points per year between } \\
2001 \text { and } 2003 \text { in rural areas }\end{array}$ & 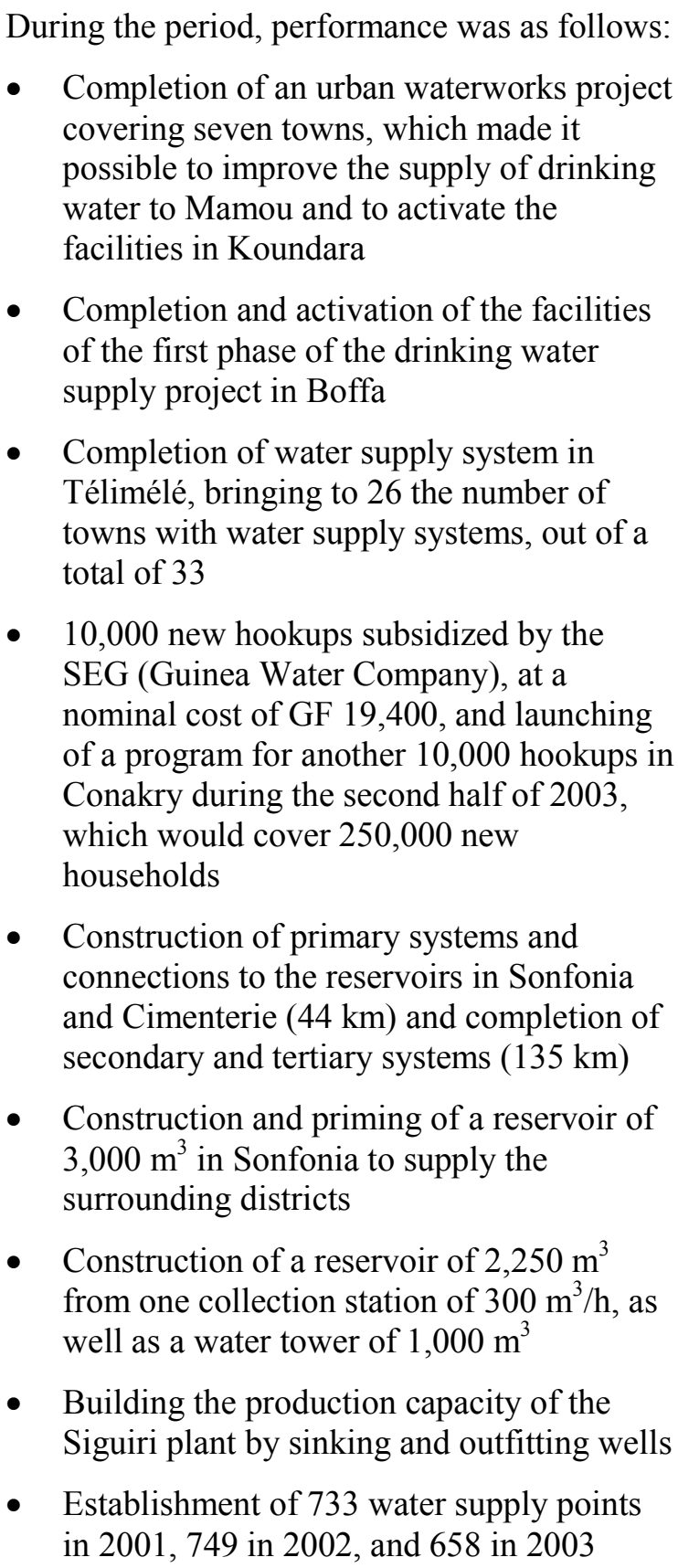 \\
\hline
\end{tabular}

30. In the rural areas, several projects to develop water supply points were extended or set up. Since the PRS was launched in 2000, 2,942 new water supply points- 
consisting mainly of wells-were completed, which increased the number of water supply points in the country to 12,358 from 9,416 at the start of 2000 .

31. Because of these projects, access to drinking water has considerably improved across the country. According to the results of the CWIQ 2002, 64.28 percent of households are less than 30 minutes away from a supply of drinking water, as opposed to 49 percent in 1999. Furthermore, 55.6 percent of households use pipe borne water or wells as their source of drinking water.

\begin{tabular}{|c|c|c|c|c|c|c|c|}
\hline & & \multicolumn{3}{|c|}{1999} & \multicolumn{3}{|c|}{2002} \\
\hline & & Urban & Rural & Overall & Urban & Rural & Overall \\
\hline \multirow{4}{*}{$\begin{array}{l}\text { Water } \\
\text { Supply } \\
\text { Source }\end{array}$} & Pipe borne & 63.7 & 4.2 & 21.2 & 73.1 & 0.9 & 21.7 \\
\hline & Well/Spring & 21.1 & 29.5 & 27.1 & 19.2 & 28.9 & 26.1 \\
\hline & Borehole & 12.0 & 34.7 & 28.2 & 5.2 & 46.8 & 34.8 \\
\hline & Other & 3.5 & 32.0 & 23.9 & 2.5 & 23.4 & 17.4 \\
\hline
\end{tabular}

Source: DHS (1999) and CWIQ (2002)

32. In the area of telecommunications, the goal was to provide adequate, quality, and affordable services. The policy was to be centered on establishing a proper legal and regulatory framework, strengthening the main enterprises in the sector, and promoting universal service that would cover the entire national territory.

33. During implementation, efforts focused mainly on extending the cellular phone network, particularly in the towns in the interior. Over the past four years, the following towns have been connected to the network: Fria, Boké, Boffa, Dubréka, Coyah, Forékariah, Kindia, Mamou, Dalaba, Pita, Labé, Kouroussa, Kankan, Siguiri, Faranah, Kissidougou, and N'Zérékoré. The total number of subscribers to SOTELGUI's cellular phone network increased from around 30,000 to 90,000 between 2000 and end-2003.

34. Though these developments help to bring the country out of isolation in terms of telecommunications, much remains to be done for the sector to reach its expected level of performance. At least $2 / 3$ of the calls made do not go through and call quality is very poor. The sector's problems have to do with the low capacity of the facilities, the lack of connections between SOTELGUI and other operators, poor management of SOTELGUI and of the sector, and weaknesses in the regulatory framework for promoting investment and for commercial and technological innovation.

35. For these reasons, with the support of the World Bank, the government has begun a review, which has led to the drafting of a sectoral policy statement, the completion of connection agreements, and the amendment of the laws, as well as the preparation of implementing laws for postal and telecommunications services.

\section{d. Support for the growth sectors}

36. According to the PRS guidelines, special support has been given to the growth sectors, in particular the rural sector, mines, tourism and hotels. 
37. In the rural sector, the main objectives were based on increased productivity in agriculture, the professionalism of small farmers, and improved access by rural producers to factors of production and outlets for their products.

38. To that end, the PRSP recommended in particular establishing a regulatory framework of incentives for economic agents, development of basic services (training, access to information and to markets), implementation of appropriate financing mechanisms, strengthening the role of rural organizations (of farmers, breeders, and fishermen). Similarly, as one of the objectives for reaching completion point, the development of 19 fishing villages was planned for 2001-2003 (6 in 2001, 6 in 2002, and 7 in 2003).

39. In implementing the strategy, besides continuing to bring the production areas out of isolation and projects to develop arable land, the government has drafted and adopted a land policy statement. Its efforts targeted:

- research and dissemination: completion and publication in 2001 of a statement on national soil exploration, development, reproduction, and dissemination of improved varieties, such as NERIKA, ${ }^{8}$ the start of soil restoration actions in Fouta Djallon, particularly by using Mucuna;

- increased funding options: through Crédit Rural, the Maison Régionale de l'Entrepreneur, the fund to support women's activities established by the government in 2003 (amounting to some GF 2 billion), the project to revitalize the food crop sectors (credit extended amounted to more than GF 7 billion). Certain lines of credit have been reinforced to make it possible to acquire equipment like rice and Guinea millet hulling equipment and mills, etc.;

- literacy education and training, particularly for women;

- distribution of inputs (fertilizers, herbicides), especially under the CBSS/NERIKA project, in collaboration with Sasakawa Global 2000;

- continued epidemiological surveillance and campaigns against major pests (2,150,000 doses of the T-1.44SR vaccine were administered in 2001-2003);

- implementation of a pilot pastoral program (PPP) for land management, support to breeders for genetic enhancement of their stock, and to continue branding.

40. Furthermore, many ongoing projects and programs, such as the project for farm restoration and support for local development (PRADEL), and the village communities support program (PACV) have been pursued and new programs and projects

\footnotetext{
${ }^{8}$ With a view to more intense cultivation of food crops in general, and rice in particular, with the support of the AfDB, a project was implemented to disseminate NERIKA. Based on a community sowing system, the project was able to cover 20 prefectures out of the country's 33, including 5/8 in lower Guinea, 4/10 in middle Guinea, 6/8 in upper Guinea, and 5/7 in forested Guinea.
} 
implemented. These include the sustainable social development program (PDSD) of upper Guinea (Madiana, Kérouané, Dinguiraye, Kouroussa, and the Kindoye CRD in Dabola) and of middle Guinea (Koubia, Tougué, Mali, and Dalaba), the second rural development support project in upper Guinea (PADERII-HG) covering Kouroussa and Siguiri, etc.

41. With regard to promoting local fishing, a program to develop 19 fishing villages was started by the government, covering 7 villages in 6 prefectures during the first phase. In addition to the development of jetties and platforms, program activities will include the construction of smoking hangars, freezer plants, mechanical repair workshops, as well as social development infrastructure. Execution of this program was greatly delayed. Technical studies were completed in 2003, and an invitation to bid on the projects was launched in June 2003.

42. In the area of mines, the government continued to enhance the framework for investment in the sector through the ongoing review of the policy letter on mining and the mining code. In addition, the government has always promoted mining mega projects with potential investors.

43. In 2003, the ministry responsible for mines received 96 applications for new projects, including 15 for authorization for geological and mining exploration, 50 for mining research permits, etc.

44. Tourism and hospitality were also counted among the growth and incomegenerating sectors for the poor. In these areas, the challenge of the PRS was to promote private investment for the enhancement and exploitation of existing potential, foster an improved supply of inputs for the crafts sector, and support professionalism in these sectors.

45. Between 2000 and 2003, the government, through the ministry responsible for these sectors, took a number of actions in pursuit of that goal. These include the organization in Conakry of the $27^{\text {th }}$ Congress of the ATA (Africa Travel Association) in 2001, training and sensitization of staff in deconcentrated units and of professionals in the sector with a view to setting up local tourism associations, organizing promotional trips abroad, preparing and signing cooperation agreement protocols with Senegal and Gambia for the promotion and use of inter-state tours, organizing workshops in Conakry and the interior of the country to raise awareness among stakeholders with a view to restructuring the crafts sector and its professional associations, with the support of the project on selfpromotion activities in the crafts sector and appropriate technologies (4A-TA), establishing a Guinean network of crafts organizations, etc.

\section{Economic performance}

46. In the last four years, Guinea's economic performance has been the worst in 10 years. The average annual GDP growth rate was 2.99 percent, as opposed to a target of 5 percent set in the PRSP. In 2003, the growth rate of GDP for the secondary sector 
(comprising mining, manufacturing, water, power, and construction) was around 0.5 percent.

\begin{tabular}{|l|rrrrrrr|}
\hline \multicolumn{7}{|c|}{ Table 3: Changes in GDP and Inflation, Guinea 1997-2003 (in percent) } \\
\hline & 1997 & 1998 & 1999 & 2000 & 2001 & 2002 & 2003 \\
\hline GDP Rate & 4.8 & 4.3 & 3.3 & 2.0 & 3.7 & 4.2 & 1.4 \\
GDP Rate Per Capita & 1.8 & 1.2 & 0.4 & -0.9 & 0.7 & 1.1 & -1.7 \\
GDP Rate, Rural Sector & 1.9 & 5.5 & 5.2 & -2.3 & 6.3 & 5.1 & 4.5 \\
GDP Rate Per Capita, Rural Sector & -0.9 & 2.0 & 2.0 & -5.8 & 2.2 & 1.9 & 1.4 \\
Inflation Rate & & 5.1 & 4.6 & 6.8 & 5.4 & 3.0 & 14.8 \\
\hline
\end{tabular}

Source: MP/DNP: Macroeconomic Framework, February 2004

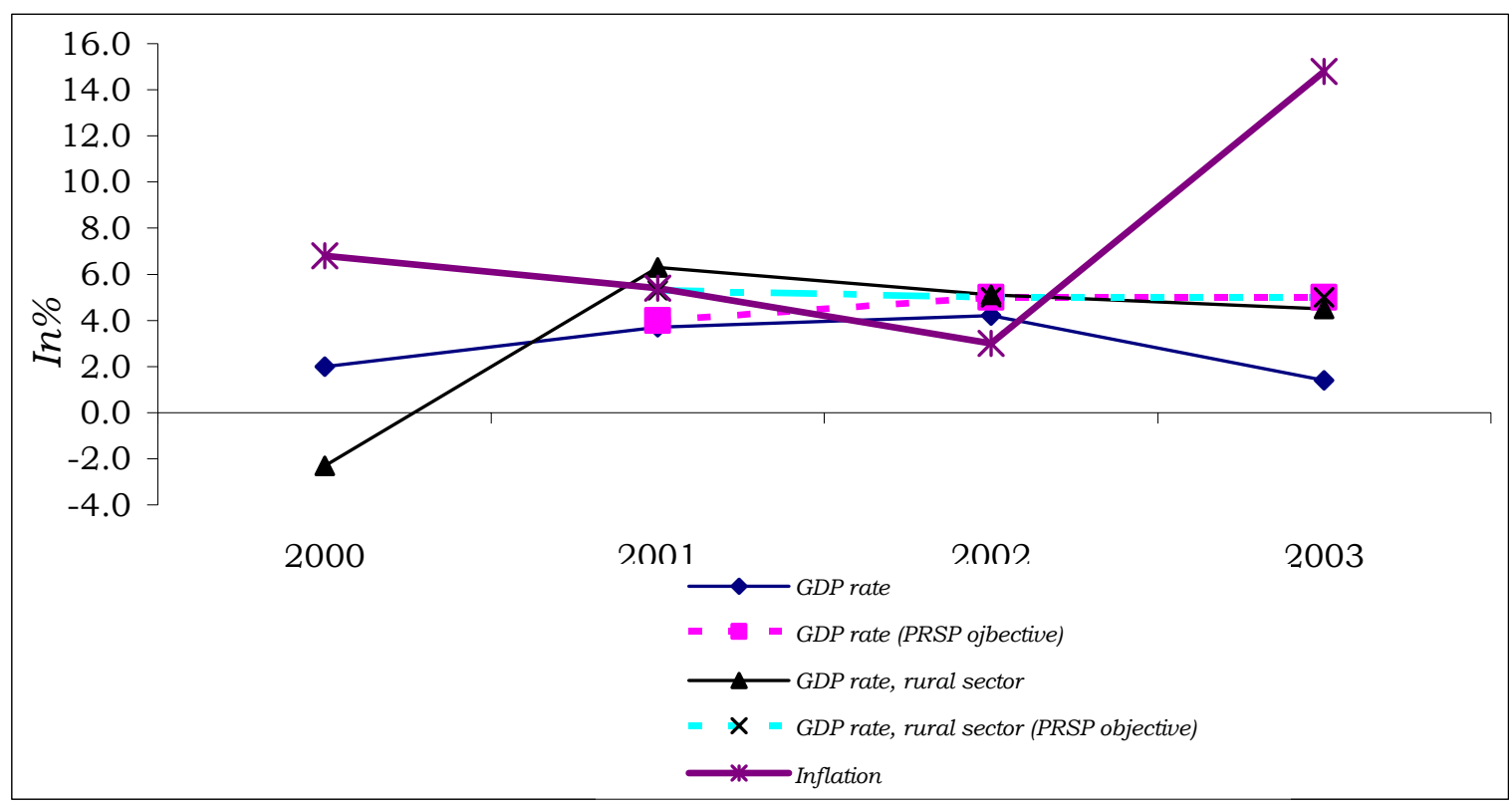

47. Besides such structural factors as the low level of investment and factor productivity, the country's economy was rocked by rebel attacks in 2000 and 2001 and by the crisis in the water and power sectors since 2002 .

\section{Pillar II: Development and Equitable Access to Basic Services}

48. The main objectives of the strategy were to improve access to services and their quality. To do so, the PRS was based on the development of basic infrastructure, the availability of adequate staff and substantial operating resources as well as the 
involvement of beneficiaries in monitoring the management of the services. The accessibility of these services to the poor and the reduction in inequalities between the regions were major challenges for the strategy.

49. To improve the quality of services, more substantial resources were mobilized for the social sectors, in particular education and health. The share of these sectors in total operating expenditure, Titles III and IV, moved from 34.7 percent in 2000 to 44 percent in 2002 and 2003 . The rate of execution of these expenditures rose to 93.7 percent in 2000 and 97 percent in 2002.

50. In addition, in compliance with the PRS guidelines, budget deconcentration was introduced in Guinea in 2001, with at least 60 percent of the current appropriations for the social sectors allocated to local units. In 2001, the share of deconcentrated units represented 65 percent of budget allocations under Titles III and IV for the social sectors, and 95 percent of the committed expenditure was executed.

\section{Education}

51. The following objectives were targeted: (i) rise the gross enrollment ratio at the primary level from 56.8 percent in 2000 to 69 percent in 2003; (ii) reach a gross enrollment ratio for girls of 60 percent in 2003 as opposed to 44.3 percent in 2000; (iii) improve the quality of education services; and (iv) reduce regional disparities. In the context of implementation, the outcomes were as follows:

\begin{tabular}{|l|r|r|r|r|}
\hline \multicolumn{4}{|c|}{ Table 4: Changes in the number of available classrooms per teacher } \\
\hline & $1999 / 00$ & $2000 / 01$ & $2001 / 02$ & $2002 / 03$ \\
\hline & \multicolumn{4}{|c|}{ Number of Classrooms } \\
\hline Public & 14,205 & 14,571 & 16,281 & 16,821 \\
Community & - & - & 401 & 427 \\
Private & 4,085 & 5,472 & 6,973 & 7,243 \\
Percent of total & 22.3 & 27.3 & 29.5 & 29.6 \\
Total & \multicolumn{5}{|c|}{} \\
\hline & & & & \\
\hline Public & 13,558 & 14,267 & 14,880 & 17,038 \\
Community & - & - & 335 & 391 \\
Private & 3,782 & 4,977 & 5,910 & 6,430 \\
Percent of total & 21.8 & 25.9 & 28.0 & 26.9 \\
Total & 17,340 & 19,244 & 21,125 & 23,859 \\
\hline
\end{tabular}

Source: Primary Education Statistics Yearbooks/MEPU-EC

52. In the public sector, 6,334 contractual teachers had their contracts renewed, while 2,332 new teachers were recruited in 2001/02 and 3,201 in 2002/03.

53. In terms of education quality, the strategy consists of controlling student/classroom and student/teacher ratios, capacity building and motivation of teaching personnel, improving the availability of textbooks, strengthening the financial capacity of units at the local level, and reinforcing the role of the communities in school monitoring and management. 
54. At the national level, the student/classroom ratio moved from 35 in 1999/2000 to 44 in 2002/2003. The regions with the highest student/classroom ratios are: Conakry (43.5 students per class, for 95 institutions in the public sector and 29 in the private sector), Kankan (47), Faranah (47), and Boké (47). In Conakry, 83 percent of the public primary schools are overcrowded when measured by the quality criterion of students per classroom, as opposed to 22 percent nationwide.

55. The student/teacher ratio rose from 44 to 46 over the same period. In 2003, the regions of Faranah and Kankan had the highest ratios with 51 and 52 students per teacher, respectively, compared with 41 for Conakry.

56. Despite some overcrowding of classrooms and overworking of teachers during the period under review, the two ratios remain within generally accepted quality criteria (of 40-60 students per classroom in urban areas and 30-60 in rural areas).

57. With a view to providing job stability and incentives for contractual teachers, the government decided to raise their monthly salaries from GF 90,000 to GF 120,000 (a 33-percent increase) and to pay them for 12 months instead of the original nine. In addition, a number of teachers joined the civil service between 2001 and 2003 after passing a qualifying examination.

\section{Outcomes:}

58. Access to education services has improved noticeably. In 2002, 75.82 percent of households had access to primary education, as opposed to 62.3 percent in $1999 .{ }^{9}$ 57.1 percent of households are less than 15 minutes away from a primary school, and only 11.5 percent of them are one hour or more away. In terms of secondary education, 9.2 percent of households are less than 15 minutes away from a school and 63.2 percent live one hour or more away.

- The gross enrolment ratio in primary school rose from 56.5 percent in 1999/2000 to 74 percent in $2002 / 03$, representing a gain of 17.5 points in three years.

- The gap between enrolment of girls and boys is gradually shrinking: the ratio of girls to total students increased from 0.40 in $1999 / 2000$ to 0.43 in 2002/03. The gross enrolment ratio for girls increased from 44.3 to 67 percent, a 22.7-point increase during the period.

59. It should be recalled that, in order to reach the completion point under the Enhanced HIPC Initiative, the objective was to attain an overall gross enrolment ratio of 69 percent and a gross enrolment ratio for girls of 60 percent in 2003, both of which have been surpassed.

\footnotetext{
${ }^{9}$ The rate of access to primary education is defined as the percentage of households living less than 30 minutes away from a primary school.
} 

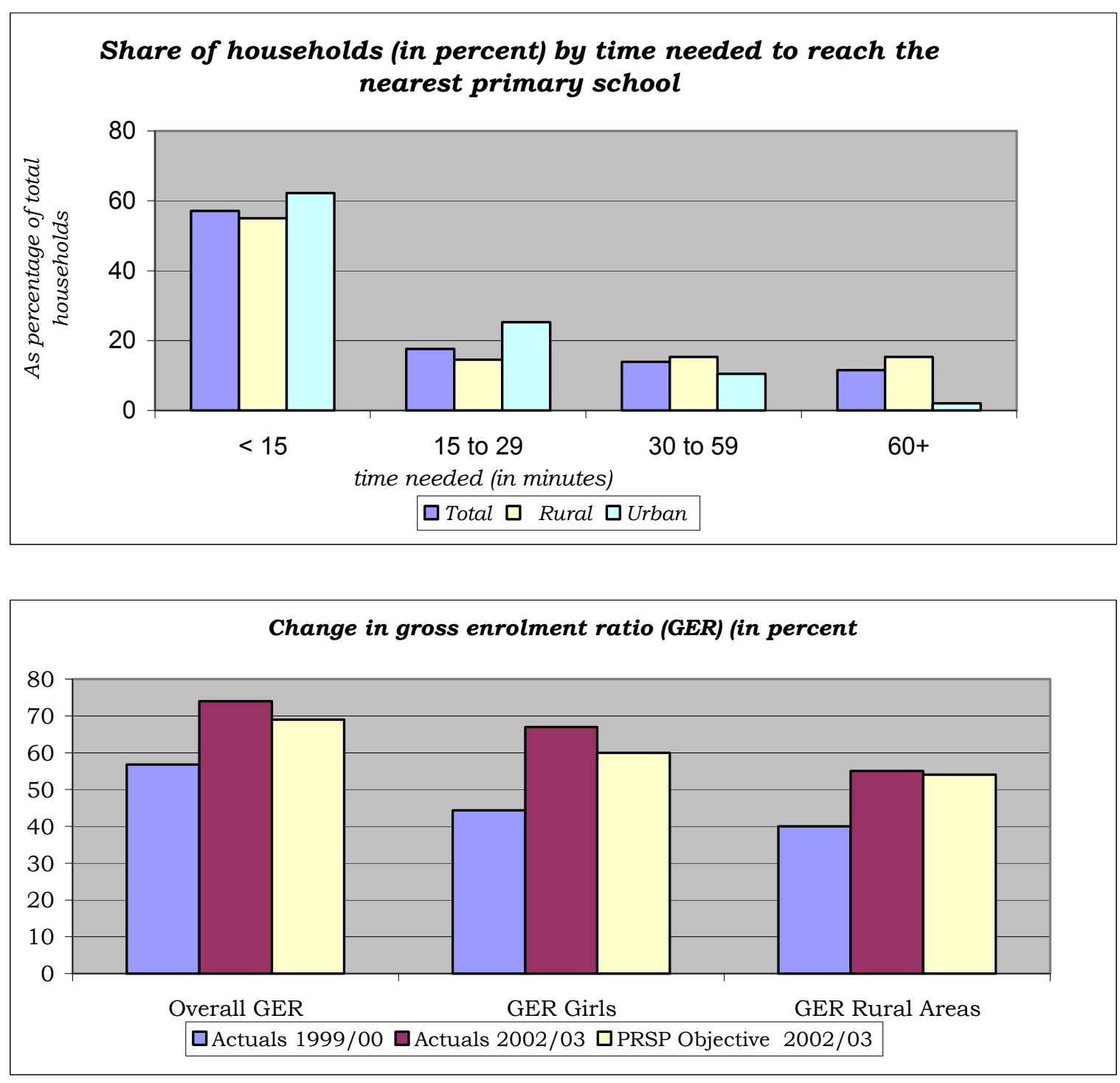

Change in gross enrolment ratio (GER) (in percent)

\section{Health}

60. Actions in the area of health involved: (i) strengthening efforts to prevent and combat priority diseases: $:^{10}$ infectious diseases (tuberculosis, poliomyelitis, diphtheria, acute respiratory infections, etc.), malaria, sexually transmissible diseases (STDs) including AIDS, (ii) promoting maternal and reproductive health, improving access by the poor to essential health services; and (iii) combating nutritional deficiencies.

61. To this end, the PRS envisaged, inter alia: extending the geographic area covered by the health facilities and developing basic community services, improving the

\footnotetext{
${ }^{10}$ Priority diseases are those that meet the following criteria: (i) are among the main causes of doctors' visits, hospitalization in health care or comfort care facilities in hospitals; (ii) represent a real threat to public health owing to their rapid spread and prevalence in the country; (iii) are responsive to interventions that are cost-effective.
} 
availability and development of essential drugs, improving the quality of care by defining a minimum package of services by health care level and implementing quality standards, establishing health councils at the community level and promoting advisory committees of users in hospitals, strengthening and expanding the immunization of children and women of child-bearing age, prophylactic treatment of malaria in pregnant women and providing care for high-risk pregnancies, promoting health cooperatives, and expanding the use of iodized salt.

62. As part of implementation, 20 new health centers and 161 new health stations were set up and became functional, bringing the total number of functional health centers to 391 and the number of health stations to 515 . These basic health facilities devote close to 80 percent of their activity to mothers and children.

63. In addition to this, the geographic coverage of community-based health care was expanded and more services offered. The new services introduced include: distribution of condoms and ivermectin (against onchocerciasis) and assisting in the prevention of malnutrition and nutritional recovery.

64. Several measures were also taken to improve the quality of services, including: the updating and expansion of an essential package of services, improving technical standards by seeking to equip facilities at all levels, and renewing all the health center management committees, user committees of the central pharmacy and advisory councils in all the hospitals, and by enhancing financial resources within the framework of budget deconcentration. In that connection, the government organized a competitive examination of the quality of all facilities in 2003, including the administrative units of the sector. ${ }^{11}$

65. In combating AIDS, sustained efforts were made by the government and its partners: implementation of a multisectoral program to combat HIV/AIDS and focal points in the fight against AIDS in all the sectors, drafting and implementation of action plans at all levels, based in particular on information, awareness, and changing behaviors toward risk, and introducing an anti-AIDS component in most public investment projects.

66. Regarding the affordability of services, over 100 cooperatives that cover risks related to pregnancy and childbirth and other health cooperatives were established locally.

\footnotetext{
${ }^{11}$ The exercise had two objectives: to let all stakeholders in the sector know what the different dimensions of quality are, ascertain the quality standards of all facilities, and establish plans and mechanisms for their improvement. To do this, six dimensions of quality were defined, each comprising sub-components with evaluation procedures and an appropriate questionnaire. After each facility completes the questionnaire, an audit mission is deployed to the field to verify the accuracy of the responses reported and, where necessary, to correct these responses and mark down the rating of any facility found to be cheating. The final results are then centralized to enable the facilities to be classified by category. The best ones would then be given a performance incentive award.
} 
67. Finally, since 2000, the program to iodize locally produced salt was revitalized and a decree signed to prohibit imports of non-iodized salt into Guinea. ${ }^{12}$

\section{Outcomes:}

68. The availability of health services increased substantially. Each of the 303 CRDs in the country has at least one functional health center under the expanded immunization, primary health care, and essential drugs program (PEV/SSP/ME); and about $3 / 4$ of the rural districts have a functional health station.

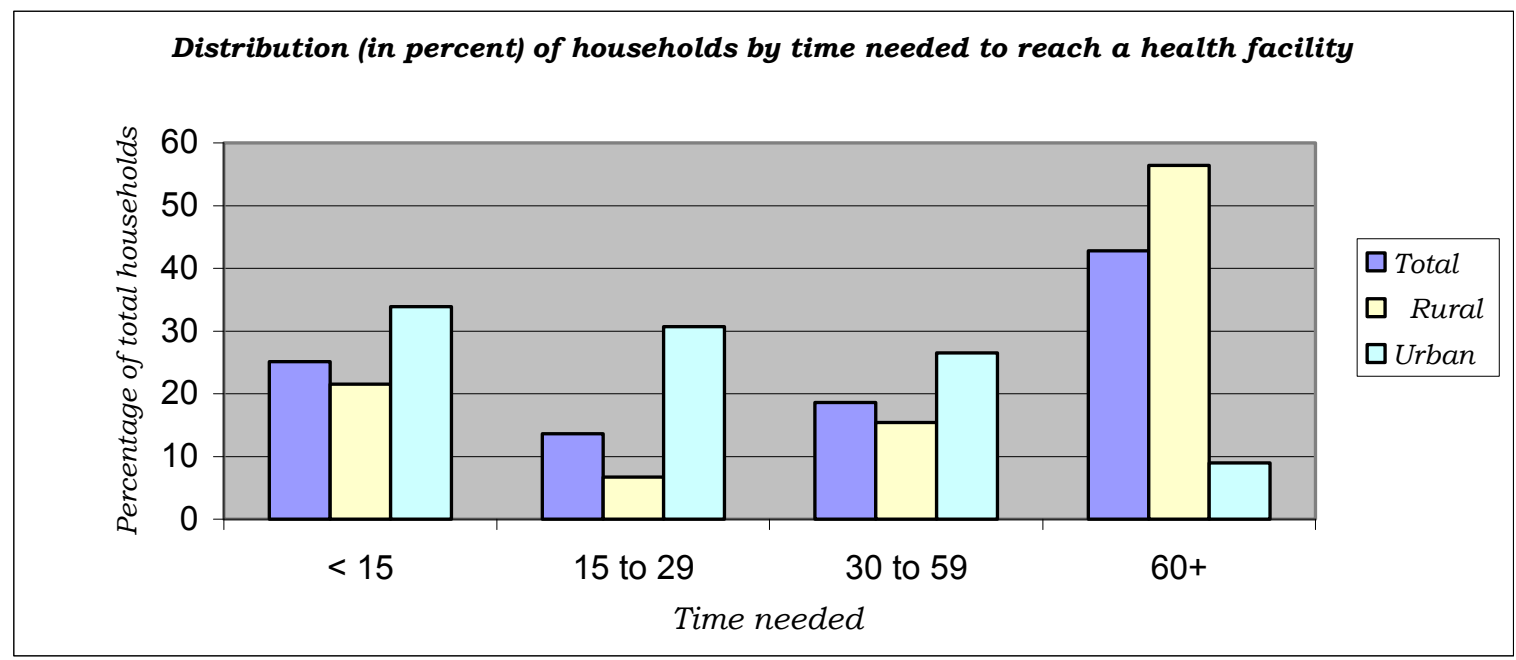

69. In terms of use of services, immunization coverage was expanded and the conditions of childbirth improved. Also, the following results were obtained in the routine $\mathrm{PEV} / \mathrm{SSP} / \mathrm{ME}$ program:

\begin{tabular}{|l|c|c|c|c|c|c|c|c|}
\hline \multicolumn{7}{|c|}{ Table 5: Immunization coverage rates (in percent) } \\
\hline \multirow{2}{*}{ Antigens (*) } & \multicolumn{2}{|c|}{2000} & \multicolumn{2}{c|}{2001} & \multicolumn{2}{|c|}{2002} & \multicolumn{2}{|c|}{2003} \\
\cline { 2 - 9 } & Target & Actual & Target & Actual & Target & Actual & Target & Actual \\
\hline BCG & & 82 & 80 & 75 & 80 & 71 & 80 & 73 \\
DTCP & & 43 & 55 & 64 & 65 & 58 & 75 & 65 \\
VHB & & - & 05 & - & 20 & - & 35 & - \\
VAR & & 40 & 55 & 59 & 65 & 61 & 75 & 70 \\
VAA & & - & 20 & - & 30 & 17 & 40 & 33 \\
VAT-2+ & & 38 & 65 & 52 & 75 & 53 & 80 & 56 \\
\hline
\end{tabular}

(*) BCG: anti-tuberculosis vaccine

DTCP: anti-diphtheria, tetanus, pertussis/poliomyelitis vaccine

$V H B$ : anti-hepatitis $B$ vaccine VAR: anti-measles vaccine

$V A A$ : anti-yellow fever vaccine $\quad V A T-2+:$ anti-tetanus vaccine $\left(2^{\text {nd }}\right.$ dose $)$

\footnotetext{
${ }^{12}$ An evaluation done in 2003 showed that the consumption of iodized salt had increased and that complaints related to iodine deficiencies (goiter) were 50 percent lower than in 1994.
} 
(**) After consultation with the partners, it was agreed to suspend the introduction of the anti-hepatitis $B$ vaccine (VHB) as part of the routine immunization program.

70. Several specific immunization campaigns were conducted, with the following campaigns carried out in 2002:

- anti-poliomyelitis screening in the prefectures of Macenta and Guéckédou (with coverage rates ranging from $98-100$ percent);

- national campaigns anti-poliomyelitis vaccination and vitamin A intake;

- immunization against measles in Conakry, with a coverage rate of 97 percent; and

- immunization against yellow fever in Conakry and Coyah, with a coverage rate of 97.7 percent.

71. In 2003, the following were recorded:

- an immunization campaign $\left(1^{\text {st }}\right.$ and $2^{\text {nd }}$ rounds $)$ against neonatal maternal tetanus in the prefectures of Mamou, Mali, Kouroussa, Kankan, Kérouané, Siguiri, Guéckédou and Faranah, with coverage rates of 92 percent for the $1^{\text {st }}$ round and 97 percent for the $2^{\text {nd }}$;

- screening against poliomyelitis in the border prefectures of Forécariah, Kindia, Mamou, Faranah, Kissidougou, Guéckédou, Macenta, Youmou, N'Zérékoré, Lola, Beyla, and Mandiana; and

- a national immunization campaign against measles.

Table 6: Distribution of births (in percent) by place of birth and type of assistance during delivery

\begin{tabular}{|c|c|c|c|c|c|c|c|}
\hline & \multicolumn{3}{|c|}{1999} & \multicolumn{3}{|c|}{2002} \\
\hline & & Urban & Rural & Overall & Urban & Rural & Overall \\
\hline \multirow{3}{*}{$\begin{array}{l}\text { Place of } \\
\text { Birth }\end{array}$} & Health Care Establishment & 60.0 & 18.9 & 29.0 & 73.3 & 23.3 & 34.8 \\
\hline & At Home & 38.6 & 79.7 & 69.5 & 24.9 & 75.9 & 64.1 \\
\hline & Other/ND & 1.4 & 1.5 & 1.4 & 1.8 & 0.8 & 1.1 \\
\hline \multirow{4}{*}{$\begin{array}{c}\text { Type of } \\
\text { Assistance }\end{array}$} & Doctor & 12.5 & 3.3 & 5.6 & 10.0 & 1.3 & 3.3 \\
\hline & Nurse/Midwife & 63.1 & 18.0 & 29.2 & 74.4 & 23.4 & 35.1 \\
\hline & Traditional Birth Attendants & 8.2 & 23.9 & 20 & 8.5 & 53.8 & 43.4 \\
\hline & Other & 14.9 & 53.4 & 43.9 & 7.2 & 21.4 & 18.2 \\
\hline
\end{tabular}

Source: DHS (1999) and CWIQ (2002)

\section{Housing and Sanitation:}

72. Four objectives were pursued in this sector: sanitation for residential areas and environmental protection, access for Guineans to decent housing with the proper utilities, improved institutional and human capacity for intervention in the sector, and reduction of regional disparities and under-servicing. 
73. In that connection, the planned actions focused on rebuilding old neighborhoods, new housing developments, establishing rainwater sanitation projects in Conakry and in the interior, establishing waste treatment centers, and improving capacity for intervention in the sector. In particular, 1,500 sanitary facilities were scheduled to be repaired, 2,000 improved latrines and 3,000 outdoor washtubs with floor drains built, and 2,500 traditional wells outfitted with curbstones.

74. Implementation included: the subdivision of the districts of Cobaya-village, Yattaya-Foula, Madina, Sofonia, Bonfi, and Dabompa-Sud; the development of new lots in Sonfonia, and the conduct of a feasibility study of a priority program for developing under-served communes in Conakry.

75. To improve the urban environment in Conakry, major efforts were made in the area of sanitation, notably:

- for public sanitation (rehabilitation of the sewerage system in Kaloum): work was started in 2003 and is continuing, as part of the $3^{\text {rd }}$ water and sanitation project;

- for semi-public sanitation: two dumping stations (Yimbaya and Sonfonia), and three waste water treatment plants in Conakry are being built; and

- for private sanitation, the following are under construction: (i) 13 lots with 2,535 sanitary projects (latrines, showers, and drains), covering 520 households in Conakry, (ii) two lots of 33 public latrines in markets, schools, and bus and taxi stations and public squares. ${ }^{13}$ The work is already 70 -percent complete.

76. In developing infrastructure and priority services in Conakry, efforts focused on: (i) solid waste management (elimination of 100 percent of uncontrolled dumping, transfer to the dump of 90 percent of the trash collected, and 33 licensed SMEs and 2,843 jobs created), (iii) opening up access to districts through Small Community Initiative Programs (PLIC) 95-percent funded by the governorate and 25-percent funded by the township and the Priority Access and Rehabilitation Programs (PROP), which are 90 percent funded by IDA and 10-percent by the budget (177.59 km of roads built).

77. Finally, a number of projects are under way in Kankan, Labé, Kindia, and N'Zérékoré: construction or repair of the communal government offices, and socioeconomic projects and facilities.

\section{Pillar III: Improved Governance and Institutional and Human Capacity Building}

78. The reforms implemented are based on deconcentration/decentralization of public management, grassroots participation and ownership, combating corruption, and building institutional and human capacity at all levels. The following measures were introduced in the area of deconcentration/decentralization:

\footnotetext{
${ }^{13}$ It should be stressed that these results do not take into account the numerous other projects and programs in progress, in particular in the rural areas. For example, the national water supply point development service built 160 shared latrines and over 1,000 household latrines in 2001 in the prefectures of Coyah, Dubreka, Forecariah, and Fria.
} 
- adoption of a new budget nomenclature in 2000 for appropriation breakdowns and monitoring of expenditures down to the recipients at the local level. After a pilot project in two regions (Conakry and Kindia) in 2001, fiscal deconcentration was extended to the entire country in 2002;

- strengthening the financial means of the local authorities through more substantial budget appropriations and by giving back all or a large share of the local taxes collected. Thus, the minimum tax on local development was surrendered in its entirety (Law L/2000/001/AN of January 26, 2000); the share of the local governments in the land tax and the small business tax was raised from 50 to 80 percent, and the share of the automobile tax from 30 to 50 percent. As a result, transfers to the local governments increased from GF 3.1 billion in 2001 (excluding the minimum local development tax) to GF 7.31 billion in 2002;

- provide the regions and prefectures with the authority to award, manage, monitor, and evaluate government contracts. In 2002, the transfer of contracts was capped at GF 100 million for the prefectures and GF 300 million for the regions. In 2003, these caps were raised to GF 300 million and GF 500 million, respectively.

79. In addition to these measures to bring the public closer to the centers of decisionmaking and management, there were other measures to increase the involvement of recipients in the monitoring and control of government actions. These include, in particular, the sensitization of all local stakeholders through various consultation workshops or rural and community radio programs, publication in the public and private media of information on resource allocations and transfers to the local level, promotion of the Associations of Parents and Friends of Schools and local health facility management committees.

80. To strengthen and institutionalize this participation, prefectoral development councils were created as a pilot project in four prefectures (Coyah, Mamou, Macenta, and Kérouané) out of the 33 in the country. Comprising representatives from the public utilities and civil society, these councils have the power to debate the prefecture's programs and budgets. They will be extended to all the prefectures in the country.

81. Also worthy of note is the support for local government capacity building, especially through the activities of the PACV. Altogether, 146 CRDs were covered by training and the local initiatives fund, compared with a target of 100 CRDs in the first phase of the program. For these 146 CRDs, 89 local development plans were drafted and validated and 57 are being validated.

82. A number of anti-corruption activities have been undertaken: (i) drafting of an anti-corruption strategy with an action plan validated by all the regions of the country; (ii) starting a number of investigations; ${ }^{14}$ (iii) setup of the equipment for four regional

\footnotetext{
${ }^{14}$ At the level of the judiciary, these investigations have not yet borne the anticipated fruit. The National Anti-Corruption Committee (CNLC) and the State Judicial Agency are constantly in touch with each other with a view to expediting decisions in corruption cases.
} 
anti-corruption field offices and production of a number of pedagogical tools (documentary film, plays in national languages, comic strips for school children, etc.) for information, sensitization and stigmatization of corruption; and (iv) organization of an awareness campaign in 12 or the 33 prefectures in the country; and (v) ongoing national survey to determine the profile of corruption and strengthen the means for combating it.

83. In the same vein, nine courthouses were repaired and equipped, compared with a target of 19 for 2001-03. Important measures were also envisaged to improve the framework of business: implementation of the uniform acts of the OHADA treaty, training for magistrates in OHADA texts, and adoption of specific statutes for the magistrates.

84. At the same time, the government took important measures to strengthen security, especially in the large urban centers. This included the setup of 13 crime fighting brigades, enhancing radio communication equipment by providing 100 new walky talkies, 15 new fixed-station HF radios, and 20 fixed-station VHF radios, introduction of the 1717-Emergency Police number, and establishment of the National Drug Prevention and Enforcement Services.

\section{LESSONS DRAWN FROM PRS IMPLEMENTATION:}

85. The slowdown in economic growth over the last four years has been very detrimental to attaining the objectives of the PRS. In addition to its negative impact on the mobilization of fiscal revenue, it limited job and income-generating opportunities for the population.

86. According to the CWIQ 2002 survey, 37.6 percent of households in the country feel that the community's economic situation was worse in 2002 than it was in 2001. Only 12.8 percent of the households observed some improvement in the situation. About 30 percent of the households stated that they often, if not always, had problems meeting their needs for food, as opposed to 27 percent of the households who stated that they rarely or never encountered difficulties with food during the year prior to the survey.

87. The participatory process established by the government played a key role in guiding and implementing the PRS. In particular, it highlighted the weaknesses related to centralized management of development actions (abandonment of projects, failure to respect quality standards, poor match between the services provided and the needs of the population, no means for control by the local authorities, etc.), as well as the very precarious conditions of work in the public services at the local level.

88. Consequently, far-reaching reforms were recommended and implemented: fiscal deconcentration, strengthening the financial power of the local governments, transfer of authority for managing government contracts to the regions and prefectures concerned, publication of information on funds mobilized and their intended use. 
89. Although there has been real progress in the deconcentration/decentralization of public spending, much remains to be done to consolidate and sustain the achievements. According to the surveys carried out within the context of the Public Expenditure Review (PERII), most sub-appropriations are committed, but the majority of spending is at the regional or prefectoral level. ${ }^{15}$ Quality control of expenditure and actions in the field by the local population and other grassroots actors is still limited.

- Almost 76 percent of children have access to school (less than 30 minutes away from a teaching establishment), but 64.4 percent of the students state that they are unsatisfied with the services provided by the schools (textbooks and supplies, quality of teaching, shortage of teachers, etc.).

- 41.8 percent of households have access to basic health care (less than 30 minutes away from a health care facility) but only 47 percent of the persons that consulted a health practitioner during the four weeks preceding the survey were satisfied with the service, as opposed to 53 percent who were dissatisfied (cost of service, ineffective treatment, shortage of drugs, unsanitary facilities, long waits, lack of trained personnel).

- There are no recent means to track changes in the opinion of the population about the quality of service. However, the references above clearly indicate the magnitude of the efforts to be made to reach the intended objectives in terms of both availability and quality of the services offered.

90. The PRS raised the hopes and enthusiasm of the people. The government also expected matching support from its partners to make strides in improving the standard of living of the population. In practice, this support has not been forthcoming, sometimes for political reasons, thereby worsening the macroeconomic framework for PRS implementation and making it difficult to achieve the objectives, as noted in the revised macro framework.

91. In light of the foregoing, the government and the other sectors involved must address the key questions of how to create the conditions for a sustained and lasting recovery of economic growth, and of how to mobilize more fiscal revenue, use it more efficiently, and improve the quality of services to the public?

92. To correct the problem and make it possible to continue PRS implementation, strong measures must be planned as soon as possible. First, the measures will be focused on getting the macroeconomic framework back on track, especially with better fiscal discipline and allocation of resources to the priority sectors. Also, the efforts made in 2002 and continued during the first half of 2003 must be resumed urgently to maintain a reasonable level of financing for the priority sectors.

\footnotetext{
${ }^{15}$ Expenditure execution at the regional or prefectoral level is largely determined by the following factors: problems committing expenditure at the rural level, no markets at the local level for most of the goods to be procured (school supplies, drugs, etc.), poor communications, and lack of experience in managing expenditure in the recipient units.
} 
93. Furthermore, within the framework of the PRS review this year, much thought must be given to activating growth and the constraints and challenges to be faced. The core considerations must be the reform the water, power and telecommunications sectors, marketing outlets for the promotion and diversification of exports, more intense exploitation of mines and development of the bauxite-alumina/aluminum industry, repatriation of export revenue to bolster the national economy, promotion of SMEs/SMIs. In any case, all the necessary measures will be taken to revitalize the basic infrastructure sectors and pave the way for government divestiture of these sectors.

94. Major projects recently carried out in the country will contribute to the choice of economic and social policies to be factored into the PRSPII. These include the Core Welfare Indicators Survey (CWIQ2), the diagnostic study on trade integration, the policy framework paper on employment promotion for development and poverty reduction in Guinea, the second public expenditure review, the socioeconomic impact study of HIV/AIDS in Guinea, the study on marginal groups, and the study on child labor.

95. Furthermore, in addition to efforts at fiscal deconcentration by the government, the systems for monitoring and control of expenditure and its incidence on the quality of services should be strengthened both within the government departments and in the local communities. Local elected officials and civil society organizations should play a more important role in improving the performance of services, by helping develop a culture of accountability of public providers to the public.

96. Within the framework of monitoring/evaluation activities, surveys will be regularly conducted to better ascertain progress in implementing the strategy, the quality of services provided, and their incidence on the welfare of the population.

\section{Summary Table of the Outcomes of PRS Implementation}

\begin{tabular}{|c|c|c|c|c|c|c|c|}
\hline \multirow{2}{*}{$\begin{array}{l}\text { Objectives/ } \\
\text { Indicators }\end{array}$} & \multirow{2}{*}{ Benchmark } & \multicolumn{3}{|c|}{ PRSP Objectives } & \multicolumn{3}{|c|}{ Actual Outcomes } \\
\hline & & 2001 & 2002 & 2003 & 2001 & 2002 & 2003 \\
\hline Incidence of poverty nationwide & $40.3 \%(1995)$ & \multicolumn{3}{|c|}{$30 \%(2010)$} & \multicolumn{3}{|c|}{-} \\
\hline \multicolumn{8}{|l|}{ Increase income } \\
\hline GDP growth (in percent per year) & $3.7(1996 / 00)$ & \multicolumn{3}{|c|}{$5.0(2002 / 05)$} & \multicolumn{3}{|c|}{$3.09(2001 / 03)$} \\
\hline GDP growth per capita (in percent) & $1.01(1996 / 00)$ & \multicolumn{3}{|c|}{$1.9(2002 / 05)$} & \multicolumn{3}{|c|}{$0.03(2001 / 03)$} \\
\hline \multicolumn{8}{|l|}{ Preserve macroeconomic and financial stability } \\
\hline Inflation rate (in percent) & $4.3(1996 / 00)$ & \multicolumn{3}{|c|}{$3.5(2005)$} & 5.4 & 3.0 & 14.8 \\
\hline $\begin{array}{l}\text { Overall fiscal balance (on a commitment basis, } \\
\text { excluding grants, in percent of GDP) }\end{array}$ & $-5.4(2000)$ & \multicolumn{3}{|c|}{$-3(2005)$} & -7.4 & -8.2 & -9.4 \\
\hline $\begin{array}{l}\text { Average external current account balance (excluding } \\
\text { official transfers, in percent of GDP) }\end{array}$ & $-6.0(2000)$ & \multicolumn{3}{|c|}{$-4(2005)$} & -6.5 & -7.7 & -5.9 \\
\hline \multicolumn{8}{|l|}{ Improve the level of education } \\
\hline Gross primary school enrolment ratio (percent) & $56.7(1999 / 00)$ & \multicolumn{3}{|c|}{$70(2004 / 05)$} & \multicolumn{3}{|c|}{$74(2002 / 03)$} \\
\hline Gross school enrolment ratio for girls (percent) & $44.3(1999 / 00)$ & \multicolumn{3}{|c|}{$63(2004 / 05)$} & \multicolumn{3}{|c|}{$67(2002 / 03)$} \\
\hline Adult literacy rate (percent) & $36(1998 / 99)$ & \multicolumn{3}{|c|}{$45(2007)$} & \multicolumn{3}{|c|}{$38(2003)$} \\
\hline Improve health & & & & & & & \\
\hline
\end{tabular}




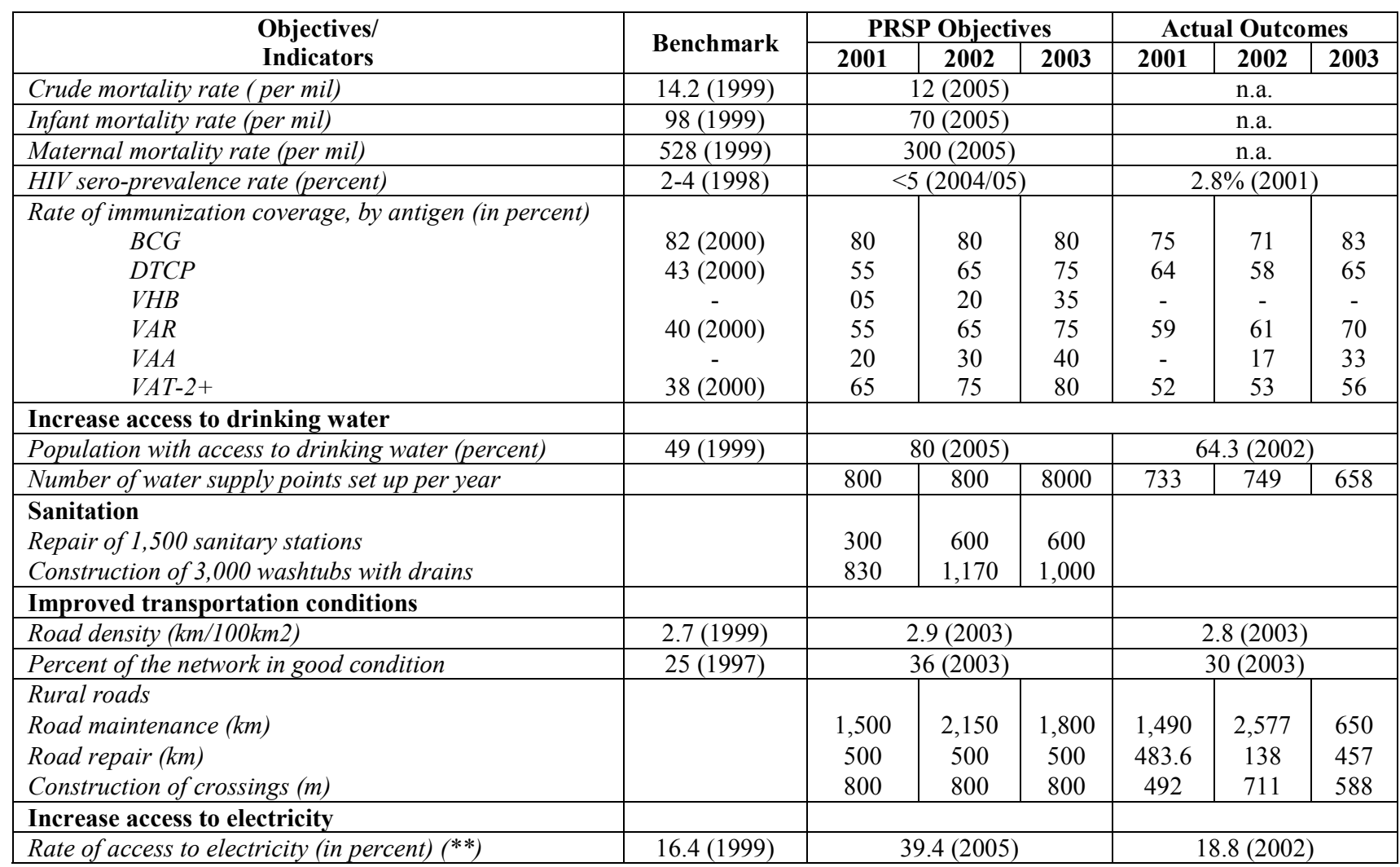

(*) Within the framework of the $3^{\text {rd }}$ Water/Sanitation project, in addition to the public and semi-public sanitation works, the following were launched: (i) 13 batches of 2,535 sanitary groups (latrines, showers, and drains), covering 520 households in Conakry, and (ii) 2 batches of 33 public latrines in markets, schools, road transport terminuses and public squares. The projects are 70-percent complete.

In addition to this, the national water supply point development service has constructed 160 shared latrines and over 1,000 household latrines in the prefectures of Coyah, Dubréka, Forécariah, and Fria. The development of sanitation infrastructure also includes a number of other ongoing projects and programs. In activating the monitoring/evaluation system designed by the government, all these products will be picked up and incorporated in the overall assessment of PRS implementation.

(**) According to the CWIQ survey carried out in 2002, 18.8 percent of households (52 percent of urban households and 1.4 percent of rural households) use electricity as a source of lighting. Only 0.3 percent of the households use electricity as a source of energy for cooking. 


\section{APPENDIX I}

\section{Updated Medium-Term Macroeconomic Framework}

97. The main medium-term (2002-05) objectives of the macroeconomic framework underlying our PRSP were to achieve an average annual growth rate of 5.2 percent driven by promoting the private sector's role in the economy; cut the inflation rate from about 7 percent in 2000 to 3.5 percent by 2005 ; reduce the overall fiscal deficit (commitment basis, excluding grants) from 7.5 percent of GDP in 2001 to 1.3 percent in 2005; and improve the external current account deficit from about 8 percent of GDP in 2000 to 4 percent in 2005. These objectives were predicated on reforms concerning: tax and fiscal policy, monetary policy, management of the financial system, debt management, privatization, and support for sub regional integration.

98. As mentioned in our PRSP Progress Report, these objectives were not achieved in large part due to exogenous shocks - continued insecurity in the sub region, declining prices for our exports, dwindling foreign financing, and below average rainfall—and also because we were unable to implement a significant number of envisaged measures (Table 1). In the event, real GDP growth declined from 4.2 percent in 2002 to 1.2 percent in 2003; average inflation which had been only 3 percent in 2002 rose significantly to about 13 percent in 2003 because of a rapid acceleration in money growth; and the overall fiscal deficit (commitment basis, excluding grants) averaged 7 percent of GDP in 200203, while social outlays declined from 1.6 percent of GDP in 2002 to 1.1 percent in 2003. However, we did meet the target for the external current account deficit which declined to 4 percent of GDP in 2003. This reflected a compression of imports of capital goods due to the significant decline in gross investment, from 13.1 percent of GDP in 2002 to only about 10 percent of GDP in 2003.

99. Due to the difficult macroeconomic context we faced in the first two years of the of the PRSP, our projections for 2004-05 are less ambitious than originally envisaged. We expect real GDP growth to remain weak in 2004-at 2.6 percent-due to the disappointing results of the first quarter, continued electricity and water cuts, and the difficulty in restoring investor confidence. We estimate the projected overall fiscal deficit (commitment basis, excluding grants) at 4 percent of GDP in 2004, with revenues reaching only about 11 percent of GDP - due to weak revenue mobilization in the first quarter-coupled with higher than projected security expenditures. To the extend that this deficit is financed by the banking system, base money would grow by about 13.7 percent and inflation would remain in high double digits. We expect the economy to begin picking up in 2005, with real GDP growth increasing to around 3.8 percent and average inflation declining to around 14 percent, with improvement in the overall fiscal deficit and the current account

100. Our revised projections suppose that the agreed emergency economic recovery program, adopted by the new government in March 2004, would stabilize and reinvigorate the economy. Key elements of our program are: reducing public services to 
a strict minimum; rigorously respecting the procedures for the commitment of expenditures strengthening fiscal administration at all levels; improving revenue collection; and eliminating unwarranted exemptions. Also, to curb monetary expansion, we plan to pursue a proactive policy of issuing treasury bills to finance the fiscal deficit rather than central bank credit and of issuing sterilization bills as needed. Moreover, to ensure improved allocation of resources and to increase the volume of foreign exchange operations in the formal sector, we plan to abandon the de facto peg of the official exchange rate against the US dollar and to liberalize the exchange rate to reflect market conditions, at the latest by the end of the third quarter of 2004.

101. In order to achieve a growth path of 5 percent or better beginning in 2006, in line with the target of the poverty reduction strategy, we plan to complement the emergency program by our own program based on decisive progress in structural reforms. Unlocking the potential of Guinea's mining sector, agriculture, fisheries, livestock, forestry and tourism, will depend on promoting growth policies and increasing the efficiency of the economy by reducing rigidities, tackling corruption, strengthening justice, and by accelerating the restructuring and privatization of the public enterprises, with special reference to the public utilities.

102. If we can achieve macroeconomic stability and implement the reform program, we could attain real GDP growth of 5 percent in 2006 and 5.5 percent in 2007, assuming a significant recovery in investment rising to around 15 percent of GDP. We expect inflation to decline progressively in 2005 to single digits in 2006-07. Our planned adoption of the WAEMU's common external tariff in 2005 and the implementation of the measures proposed by the 2004 IMF-FAD mission, non-mining revenue would rise from 9 percent of GDP in 2004 to around 10.3 percent of GDP in 2007. Assuming we can maintain our control of expenditures, while shifting resources from non-productive sectors to priority sectors, we expect the overall fiscal deficit to decline, enabling a net repayment of bank credit to the government, with moderate money growth. Renewed growth would be accompanied by a recovery in exports, with further improvement in the current account. 
Table 1. Guinea: Selected Economic and Financial Indicators, 2002-07

\begin{tabular}{|c|c|c|c|c|c|c|}
\hline & 2002 & 2003 & 2004 & 2005 & 2006 & 2007 \\
\hline & & Est. & & $\operatorname{Pr}$ & & \\
\hline & \multicolumn{6}{|c|}{ (Annual percentage change, unless otherwise indicated) } \\
\hline $\begin{array}{l}\text { Income } \\
\text { GDP at constant prices }\end{array}$ & 42 & 12 & & 38 & 50 & \\
\hline GDP at current prices & 7.1 & $\begin{array}{r}1.2 \\
13.7\end{array}$ & 19.2 & $\begin{array}{r}3.8 \\
15.6\end{array}$ & $\begin{array}{r}5.0 \\
11.9\end{array}$ & $\begin{array}{r}3.5 \\
12.0\end{array}$ \\
\hline GDP deflator & 2.8 & 12.3 & 16.2 & 11.4 & 6.6 & 6.2 \\
\hline \multicolumn{7}{|l|}{ Consumer prices } \\
\hline Average & 3.0 & 12.9 & 16.6 & 13.8 & 8.0 & 4.9 \\
\hline End of period & 6.1 & 14.8 & 18.0 & 10.5 & 6.0 & 4.0 \\
\hline \multicolumn{7}{|l|}{ External sector } \\
\hline Exports, f.o.b. (in U.S. dollar terms) & -2.0 & 2.3 & 1.2 & 5.6 & 9.3 & 9.3 \\
\hline Imports, f.o.b. (in U.S. dollar terms) & 6.1 & -3.0 & 0.0 & 7.0 & 8.1 & 9.1 \\
\hline Terms of trade & & & & & & \\
\hline Percentage change & 2.3 & -2.9 & -4.0 & 3.4 & 0.9 & 1.7 \\
\hline Average effective exchange rates (depreciation -) & & & & & & \\
\hline Nominal index & -3.3 & -11.3 & $\ldots$ & $\ldots$ & $\ldots$ & $\ldots$ \\
\hline Real index & -2.3 & -2.7 & $\ldots$ & $\ldots$ & $\ldots$ & $\ldots$ \\
\hline \multicolumn{7}{|l|}{ Money and credit } \\
\hline Net foreign assets $1 /$ & -11.9 & -9.4 & -4.6 & $\ldots$ & $\ldots$ & $\ldots$ \\
\hline Net domestic assets $1 /$ & 31.2 & 44.7 & 24.6 & $\ldots$ & $\ldots$ & $\ldots$ \\
\hline Net claims on government ( net) $1 /$ & 34.2 & 34.0 & 19.1 & $\ldots$ & $\ldots$ & $\ldots$ \\
\hline Credit to nongovernment sector $1 /$ & 3.5 & 8.6 & 2.9 & $\ldots$ & $\ldots$ & $\ldots$ \\
\hline Broad money & 19.2 & 35.3 & 20.0 & $\ldots$ & $\ldots$ & $\ldots$ \\
\hline \multirow[t]{2}{*}{ Reserve money } & 18.3 & 27.4 & 13.7 & $\ldots$ & $\ldots$ & $\ldots$ \\
\hline & \multicolumn{6}{|c|}{ (In percent of GDP, unless otherwise indicated) } \\
\hline \multicolumn{7}{|l|}{ Central government finances } \\
\hline Total revenue and grants & 13.8 & 13.2 & 12.4 & 13.3 & 13.5 & 13.7 \\
\hline Of which: nonmining revenue & 9.8 & 9.0 & 9.1 & 9.8 & 10.0 & 10.3 \\
\hline Current expenditure & 12.2 & 12.9 & 9.8 & 9.8 & 9.5 & 9.5 \\
\hline Capital expenditure and net lending $2 /$ & 6.0 & 5.5 & 5.2 & 5.8 & 5.9 & 6.0 \\
\hline \multicolumn{7}{|l|}{ Overall budget balance } \\
\hline Including grants (commitment) & -4.4 & -5.1 & -2.6 & -2.2 & -2.0 & -1.8 \\
\hline Excluding grants (commitment) & -6.2 & -7.9 & -4.1 & -3.9 & -3.6 & -3.3 \\
\hline Primary balance & 0.0 & -1.6 & 1.6 & 1.6 & 1.7 & 1.7 \\
\hline Gross investment & 13.1 & 9.9 & 10.5 & 11.5 & 13.4 & 15.5 \\
\hline Government $3 /$ & 4.0 & 3.8 & 3.6 & 4.0 & 4.1 & 4.2 \\
\hline Nongovernment & 9.1 & 6.2 & 6.9 & 7.5 & 9.3 & 11.3 \\
\hline Domestic savings & 9.1 & 7.4 & 8.6 & 9.7 & 12.1 & 14.4 \\
\hline Government & 1.5 & -0.3 & 3.2 & 3.7 & 3.9 & 4.1 \\
\hline Nongovernment & 7.7 & 7.7 & 5.4 & 6.0 & 8.2 & 10.3 \\
\hline \multicolumn{7}{|l|}{ External current account balance } \\
\hline Including official transfers & -4.3 & -3.3 & -2.9 & -2.3 & -1.7 & -1.4 \\
\hline Excluding official transfers & -5.6 & -4.0 & -3.7 & -3.3 & -2.6 & -2.3 \\
\hline Overall balance of payments & -2.6 & -2.6 & -1.8 & 0.1 & 0.9 & 0.8 \\
\hline External public debt (in percent of export earnings) & 387.9 & 420.9 & 399.3 & 360.7 & 316.5 & 275.1 \\
\hline
\end{tabular}

1/ In percent of broad money stock at beginning of period.

2 / Includes expenditure for restructuring.

3/ Fixed capital formation. 


\section{APPENDIX II}

\section{MOBILIZATION AND USE OF HIPC RESOURCES}

Guinea was declared eligible to the HIPC Initiative in December 2000 and, as a result, was granted debt relief in the amount of US\$800 million, in nominal terms or US\$545 million in net present value terms. This relief has been shared among the creditor groups as follows: multilateral creditors ( 60.18 percent), bilateral creditors (39.44 percent), and commercial creditors ( 0.38 percent).

To implement the initiative, a provision to mobilize, manage, and monitor the use of HIPC resources was introduced in accordance with a ministerial instruction dated June 20, 2001. This instruction established the fiscal and accounting procedures applicable to operations involving HIPC resources. ${ }^{16}$

In that connection, a generic account called "HIPC Treasury Operations" was opened with the central bank and a unit responsible for monitoring and evaluation of those resources was set up in the National Budget Directorate. In order to track these resources, an identifier was introduced in the budget nomenclature to distinguish transactions using HIPC resources.

The table below presents a progress report on mobilization of HIPC resources (in thousands of GF):

\begin{tabular}{|l|r|r|r|r|}
\hline & \multicolumn{1}{|c|}{2001} & \multicolumn{1}{|c|}{2002} & \multicolumn{1}{c|}{ Total } \\
\hline Estimates & $107,191,000$ & $83,280,000$ & $96,290,000$ & \multicolumn{1}{c|}{$286,761,000$} \\
& & & & \\
Actuals & $40,056,000$ & $69,531,000$ & $81,900,000$ & $191,487,000$ \\
Rate of execution & $37,4 \%$ & $83.5 \%$ & $85.05 \%$ & $66.78 \%$ \\
\hline
\end{tabular}

The tables below show resource use (in thousands of GF):

In 2001:

\begin{tabular}{|l|r|r|r|r|r|}
\hline & $\begin{array}{c}\text { Wages \& } \\
\text { Salaries }\end{array}$ & $\begin{array}{c}\text { Other } \\
\text { Goods \& } \\
\text { Services }\end{array}$ & $\begin{array}{c}\text { Subsidies \& } \\
\text { Transfers }\end{array}$ & Investment & TOTAL \\
\hline Ministry of Health & - & - & 500,000 & - & 500,000 \\
Ministry of Social Affairs & 119,700 & - & - & - & 119,700 \\
MEPU-EC (*) & $2,245,090$ & $2,377,305$ & - & 174,743 & $4,797,138$ \\
Ministry of Hyd. and Energy & - & - & - & - \\
\hline Total & $2,364,790$ & $2,377,305$ & 500,000 & 174,743 & $5,416,838$ \\
\hline
\end{tabular}

(*) MEPU-EC: Ministry of Pre-University and Civic Education

\footnotetext{
${ }^{16}$ The procedures for mobilizing the resources are simplified: (i) commitment of the equivalent in Guinean francs of debt service due by the National Debt and Public Investment Directorate; (ii) validation of the commitment by the Financial Control Directorate; (iii) payment authorization by the National Budget Directorate; (iv) payment of the expenditure by debiting the Treasury account and crediting a generic HIPC account.
} 
In 2002:

\begin{tabular}{|l|r|r|r|r|r|}
\hline & $\begin{array}{c}\text { Wages \& } \\
\text { Salaries }\end{array}$ & $\begin{array}{c}\text { Other } \\
\text { Goods \& } \\
\text { Services }\end{array}$ & $\begin{array}{c}\text { Subsidies \& } \\
\text { Transfers }\end{array}$ & Investment & TOTAL \\
\hline Ministry of Health & - & $14,329,000$ & $7,868,533$ & - & $22,197,533$ \\
Ministry of Social Affairs & - & 96,750 & - & - & 96,750 \\
MEPU-EC & $14,862,262$ & $9,490,520$ & - & $8,000,000$ & $35,352,782$ \\
Ministry of Hyd. and Energy & - & - & - & $5,400,000$ & $5,400,000$ \\
Ministry of Agriculture \& Livestock & - & $6,300,000$ & - & $8,300,000$ & $14,600,000$ \\
Ministry of Justice & - & - & - & 830,000 & 830,000 \\
\hline Total & $14,862,262$ & $30,216,270$ & $7,868,533$ & $22,530,000$ & $75,472,065$ \\
\hline
\end{tabular}

In 2003:

\begin{tabular}{|l|r|r|r|r|r|}
\hline & $\begin{array}{c}\text { Wages \& } \\
\text { Salaries }\end{array}$ & $\begin{array}{c}\text { Other } \\
\text { Goods \& } \\
\text { Services }\end{array}$ & $\begin{array}{c}\text { Subsidies \& } \\
\text { Transfers }\end{array}$ & Investment & TOTAL \\
\hline Ministry of Health & 200,000 & $7,904,925$ & $3,988,297$ & - & $12,093,222$ \\
Ministry of Social Affairs & - & 89,500 & 187,500 & - & 277,000 \\
MEPU-EC & $22,725,900$ & $6,416,917$ & - & $1,501,276$ & $30,644,093$ \\
Ministry of Hyd. and Energy & - & - & - & $6,945,671$ & $6,945,671$ \\
Ministry of Agriculture \& Livestock & - & - & - & $4,288,307$ & $4,288,307$ \\
Ministry of Fisheries and Aquaculture & 50,000 & - & - & - & 50,000 \\
Ministry of Justice & 150,000 & 86,857 & - & 138,069 & 138,069 \\
Joint Expenditure & $23,125,900$ & $14,498,199$ & $4,175,797$ & $12,868,323$ & - \\
\hline Total & & & & & 236,657 \\
\hline
\end{tabular}




\section{PROCESS OF PRS FORMULATION AND IMPLEMENTATION}

\subsection{STAGES OF THE PROCESS}

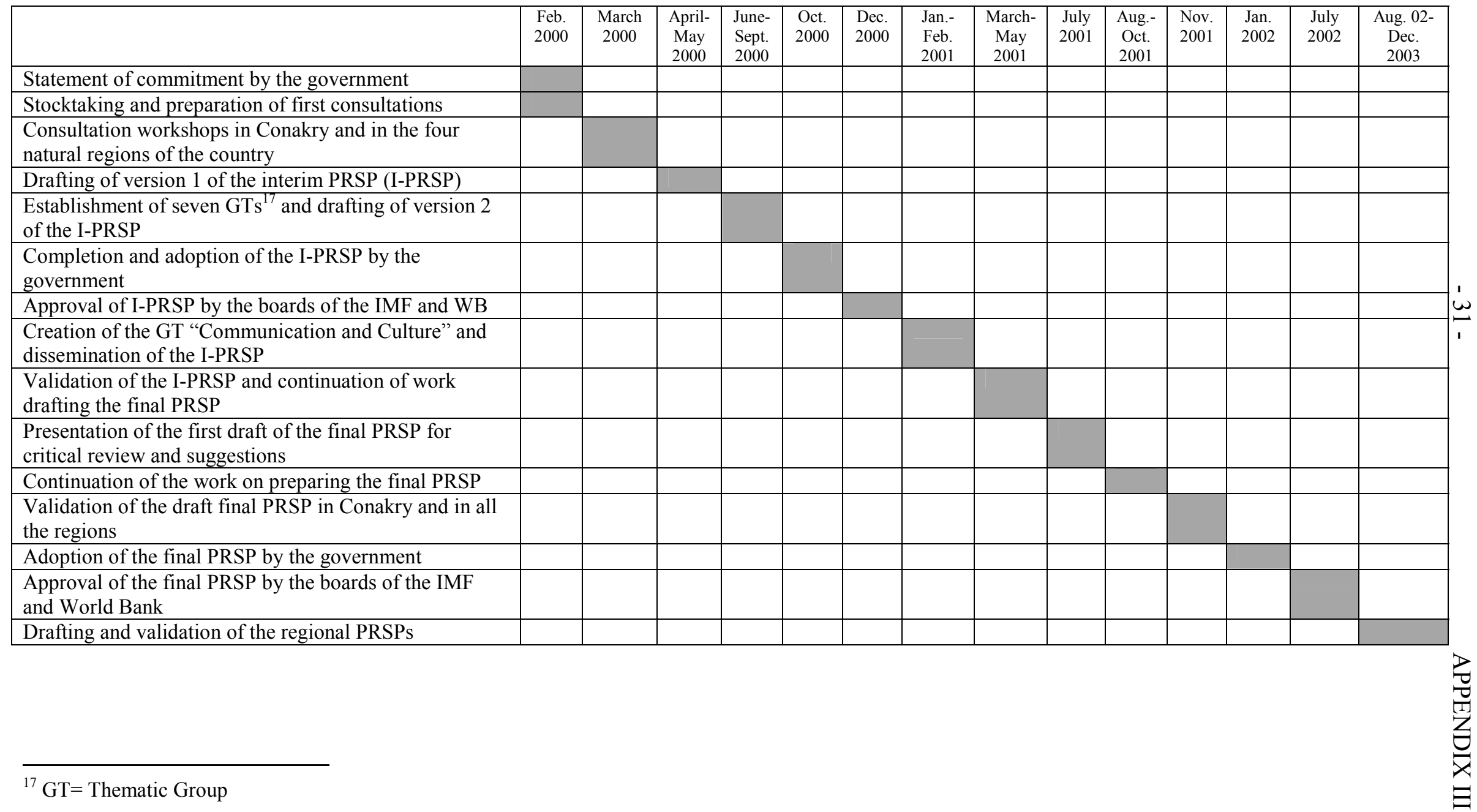




\subsection{PARTICIPATORY APPROACH}

Since the start of the PRSP process in February 2000, participation by all stakeholders was a key guiding principle in the formulation and implementation of the strategy. That approach was chosen in response to the following concerns:

- to find an appropriate strategy that responds to the key concerns of the population, in particular the poor;

- to improve both the quality of decisions and the decision-making process in the management of public affairs; and

- to ensure that the government's actions are more efficient and that permanent ground is gained.

To meet these concerns and involve all segments of the society, different participation mechanisms were put in place: direct consultation with grassroots communities, fora for consensus building and joint reflection at the central level, and debates on poverty and on poverty reduction resources at all levels.

\section{a) Direct consultation}

The aim was to understand poverty as it is perceived by the public in its daily life. The purpose was also to outline a new strategy, with the same population, based on the dynamics of growth at the grassroots. Finally, the challenge was to discuss the public's responsibility in formulating, managing, monitoring, and evaluating development actions.

To do so, since the process was launched, the government has organized four series of grassroots consultation workshops in Conakry and in the natural or administrative regions of the country:

- in March 2000, to take stock of the public's perceptions of poverty and their proposals and suggestions for poverty reduction;

- in May/June 2001, to re-draft and validate the interim PRSP and, at the same time, hear the new concerns voiced by the public;

- in November 2001, to re-draft and validate the final PRSP;

- in May 2002, a national workshop on implementation of the strategy;

- in August/September 2002, to launch the process of preparing regional poverty reduction strategies; 
- in September/October 2003, re-drafting and validation of the regional PRSPs.

The choice of participants covered mainly the poor or vulnerable population groups (women who live in rural areas or are wards of the court, street children, senior citizens, laid off employees, unemployed graduates, persons living with AIDS, etc.). The workshops were led by well-trained and experienced facilitators.

\section{b) Consensus-building and reflection at the central level}

Appropriate forums were created, gradually, based on the progress of the process, namely:

- creation of a national committee in charge of the strategy, comprising representatives of the ministerial departments, the university, and NGOs (February 2000);

- creation of seven thematic groups co-chaired by the government and civil society, responsible for further probing certain key dimensions of the strategy, such as the macroeconomic framework and the growth sectors; good governance, decentralization, and capacity building; the gender, population, and development dimension; the grassroots social sectors; combating HIV/AIDS (July 2000);

- creation of a permanent framework for consensus building, chaired by the Minister of Economy and Finance and comprising the ministers of the priority sectors, representatives of the republican institutions and civil society organizations, as well as representatives in Guinea of key institutions and development partners. This framework provides a forum for discussing the evolution of the PRSP process and exchanging views on any other questions about the economic and financial management of the country;

- creation of a Thematic Group responsible for Communication and Culture (February 2001). Connected to the local communities by traditional communicators and rural radio, this group supports the process by formulating and implementing a communication strategy adapted to the local context. It largely comprises private sector media professionals;

- creation in October 2002 of a Thematic Group in charge of designing and activating the system for monitoring and evaluation of the strategy. This group has a network of monitoring and evaluation units at the regional, prefectoral, and sub-prefectoral levels. Forums for consensus-building, patterned on the one set up at the national level, are also planned at all the levels for open debate among all local development actors. These forums are co-chaired by government and civil society representatives. 


\section{c) Debates on poverty}

The challenge was to take the problem of development and poverty reduction in Guinea to the public. Using this approach, the process involved:

- a number of sessions of discussion with the parliament, economic and social council, university, labor unions, NGOs, etc.;

- ongoing exchanges of views through the national radio and television, the written press (public and private);

- leading debates on rural and community radio;

- reflection and debates at the local level, within the communities.

An important communications pillar was established, the aim being to create and develop communications and leadership dynamics around the strategy and its implementation, and to strengthen the participatory approach. This has led to the creation of a PRS Newsletter (bimonthly), which aims to promote and disseminate the PRS. Its content is intended to make PRS implementation visible by making the voices of people on the ground heard, as they are more likely to have concrete and useful information to share. It is an ideal forum for stakeholders to air their thoughts on PRS implementation, results, and inadequacies, as well as on the challenges that must be met in order to attain the objectives.

A Permanent Secretariat Web site became operational. The site has about 15 columns that discuss mainly the content of the PRS and the various aspects of its implementation.

Communication and participation activity has also been conducted by traditional communicators, even in the most remote local entities, namely the CRDs and the districts. Traditional communicators are resource persons who are completely fluent in the national languages and have a good understanding of the content of the PRS and its implementation mechanisms. They play a decisive role since $70-80$ percent of the population is illiterate.

Focal points are being established at the regional, prefectoral, communal, and community levels. These are local leaders of the PRS implementation and monitoring/evaluation facilities; trainers and advisors in the design and implementation of local development actions; interfaces who must provide IEC for local entities and communication facilitators who must promote the participation at the local level by civil society and grassroots groups in the iterative PRS process; managers of the feedback process in their areas of intervention. 


\section{APPENDIX IV}

\section{PRS MONITORING AND EVALUATION SYSTEM}

According to the recommendations for the national workshop on the conditions for implementing the strategy, which was held in Conakry, May 6-7, 2002, the government set up a thematic group in the PRS Permanent Secretariat that was specifically in charge of monitoring and evaluating implementation of the strategy. The group had a mandate to design the monitoring and evaluation system and activate it. More specifically, the group is responsible for:

- designing the system and monitoring its implementation;

- setting up and managing an information system for PRS monitoring;

- preparing the annual progress report on strategy implementation and the performance recorded (implementation of the reforms, expenditure execution, tracking indicators, etc.);

- preparing the annual report on monitoring progress toward the Millennium Development Goals (MDGs);

- preparing the report on the annual poverty monitoring survey;

- preparing the summary of the poverty survey reports;

- participating in the impact evaluation of the strategy.

Like the groups established for drafting the PRS, the thematic group on monitoring and evaluation comprises representatives of the ministerial departments, republican institutions, civil society, and development partners. After one year of work, a system to monitor strategy implementation was defined and validated by all the stakeholders concerned in Conakry and in the interior.

a) Conceptual framework of the monitoring and evaluation system

The design and setup of the monitoring and evaluation system are guided by the following principles:

- the monitoring and evaluation system is a key element for the effective and successful implementation of the PRS. It must provide updated, regular, and relevant information on the status of implementation of the strategy, the progress made, and the impact on the population's living standards;

- the system is based on a single, all-encompassing, and consensual frame of reference; it is shared and benefits from the support of all the national stakeholders;

- the system is based on the existing structures and encompasses the various current monitoring and evaluation systems; 
- the beneficiaries of the government's actions play a more important role in the monitoring and evaluation system, which assumes that mechanisms will be adapted to enable grassroots communities and actors from the different social groups to have a say.

b) Indicators for monitoring the PRS

Based on the objectives and indicators defined in the PRSP, 62 indicators called " 1 " tier indicators" were chosen for overall PRS monitoring. These are composite indicators, which can be used to track the overall evolution of poverty in the country. For example:

- the percentage of the population living below the poverty line;

- the percentage of the population that does not have the minimum caloric intake (extreme poverty);

- the gross school enrolment ratio;

- the maternal and infant mortality rates.

These are supplemented by 61 other indicators called " 2 nd -tier indicators" used to analyze and explain developments in poverty. For example:

- growth rate of GDP per capita;

- investment rate as a percentage of GDP;

- share of the state budget per priority sector.

These indicators are used to monitor PRS performance at the macro, sectoral, and regional levels. They were selected from among the 174 indicators defined in the PRSP, as well as the 48 indicators established to monitor the Millennium Development Goals (MDGs). They also take into account the indicators that our principal development partners-including IDA and the European Union - use to monitor progress.

The choice of indicators is based on the following criteria:

- relevance as a criterion of validity; it is possible to ensure that the indicator used meets the specific objective and the targets set. Additional or alternative indicators might also be relevant;

- sensitivity of the indicator, which reflects its capacity to correctly track the evolution of the phenomenon studied; 
- reliability, reflected in the method of investigation, the quality control process, and the production of data;

- timeliness, which makes it possible to ascertain the regularity or periodicity of production of the information required (half-yearly, annual, biweekly data, etc.);

- breakdown of the indicator, which makes information available on the various administrative levels (country, region, prefecture, sub prefecture).

c) Institutional framework

To monitor its development programs and projects, the government has implemented several systems for the production and management of information, at the sectoral level (education, health, rural development, village waterworks, etc.), and within projects and programs (Village Community Support Program-PACV, and Population and Reproductive Health Project-PPSG, etc.).

The challenge is to implement an integrated system that would provide synergies and complementarities between all these systems. To that end, the institutional system comprises various organs (at the central, sectoral, and deconcentrated levels), with well-defined responsibilities:

- the PRS Permanent Secretariat, to which the thematic groups report, including the GT on monitoring and evaluation. The GT is supported by a technical unit comprising three national experts (one statistician-economist, one sociologist, and one survey statistician);

- an interministerial committee, chaired by the Minister of Economy and Finance and comprising the ministers of the priority sectors and the Minister of Planning;

- a permanent framework for consensus building, comprising an interministerial committee expanded to include the republican institutions, civil society organizations, and development partners. It plays the role of decision-making and guiding body;

- sectoral units in charge of monitoring/evaluation, under the supervision of the general secretaries of the departments involved;

- at the deconcentrated level, the system comprises a technical committee for monitoring/evaluation and a consensus-building committee at the regional, prefectoral, and subprefectoral levels. 
To illustrate, the regional technical committee on monitoring and evaluation comprises 12 members and is chaired by the Director of the Office of the Governor and assisted by the Regional Director for Planning as Vice-Chair. Its main mission is to:

- centralize prefectoral reports and draft half-yearly reports on implementation of the regional PRSP;

- transmit the report to the regional committee on consensus-building and coordination and to the PRSP Secretariat; and

- manage the trend chart of regional monitoring indicators.

The regional council on consensus-building and coordination, for its part, comprises 32 members who represent all the actors involved in regional development. It is chaired by the Governor, who is assisted by the President of the Regional Civil Society Council as ViceChair. The regional consensus-building and coordination council discusses and makes all the important decisions concerning implementation of the regional strategy (monitoring, evaluation, and iterative process).

d) Activation of the monitoring and evaluation system

In the context of activating the PRS monitoring and evaluation system, the main actions taken are as follows:

- Conduct of the CWIQ (unified Core Welfare Indicators Questionnaire) and the integrated core survey for poverty assessment (EIBEP). The results of these two surveys will be used to update the core information on poverty and constitute a reference for monitoring and evaluating PRS performance.

- Identification of 123 indicators for monitoring implementation of the strategy based on a logical framework of analysis of the indicators (relevance, sensitivity, reliability, timeliness, ability to be broken down, and observability) and their classification as first tier and second tier indicators and by typology (inputs, outputs, and impacts).

- Definition of monitoring and evaluation organs and their mission.

- Validation of this system by all national stakeholders.

- Establishment of a database to track the indicators.

- Establishment of a poverty mapping unit since 2002 (awareness and targeting of actions).

- Setup of the technical monitoring and evaluation unit. 
- Construction of a policy impact simulation model under way (macroeconomic framework model).

- Preparation of the first national report on implementation of the poverty reduction strategy.

- Preparation of the second national report on monitoring progress toward the Millennium Development Goals. 